\title{
Diversity of lichens and bryophytes in hybrid aspen plantations in Estonia depends on landscape structure
}

\begin{tabular}{|c|c|}
\hline Journal: & Canadian Journal of Forest Research \\
\hline Manuscript ID & cjfr-2017-0080.R1 \\
\hline Manuscript Type: & Article \\
\hline Date Submitted by the Author: & 23-May-2017 \\
\hline Complete List of Authors: & $\begin{array}{l}\text { Randlane, Tiina; University of Tartu, Institute of Ecology and Earth } \\
\text { Sciences, Department of Botany, Lai } 40 \\
\text { Tullus, Tea; Estonian University of Life Sciences, Institute of Forestry and } \\
\text { Rural Engineering } \\
\text { Saag, Andres; University of Tartu, Institute of Ecology and Earth Sciences, } \\
\text { Department of Botany, Lai } 40 \\
\text { Lutter, Reimo; Estonian University of Life Sciences, Institute of Forestry } \\
\text { and Rural Engineering } \\
\text { Tullus, Arvo; University of Tartu, Institute of Ecology and Earth Sciences, } \\
\text { Department of Botany, Lai } 40 \\
\text { Helm, Aveliina; University of Tartu, Institute of Ecology and Earth Sciences, } \\
\text { Department of Botany, Lai } 40 \\
\text { Tullus, Hardi; Estonian University of Life Sciences, Institute of Forestry and } \\
\text { Rural Engineering } \\
\text { Partel, Meelis; University of Tartu, Institute of Ecology and Earth Sciences, } \\
\text { Department of Botany, Lai } 40\end{array}$ \\
\hline Keyword: & bryophytes, forest continuity, forest plantations, hybrid aspen, lichens \\
\hline $\begin{array}{r}\text { Is the invited manuscript for } \\
\text { consideration in a Special } \\
\text { Issue? : }\end{array}$ & N/A \\
\hline
\end{tabular}




\section{Diversity of lichens and bryophytes in hybrid aspen plantations in}

4 Tiina Randlane, Tea Tullus, Andres Saag, Reimo Lutter, Arvo Tullus, Aveliina Helm, Hardi Tullus, and Meelis Pärtel

7 T. Randlane, A. Saag, A. Tullus, A. Helm, and M. Pärtel. Department of Botany,

8 Institute of Ecology and Earth Sciences, University of Tartu, Lai 38-40, Tartu 51005,

9 Estonia (emails: tiina.randlane@ut.ee; andres.saag@ut.ee; arvo.tullus@ut.ee;

10 aveliina.helm@ut.ee; meelis.partel@ut.ee).

11 T. Tullus, R. Lutter, and H. Tullus. Department of Silviculture, Institute of Forestry and

12 Rural Engineering, Estonian University of Life Sciences, Kreutzwaldi 5, Tartu 51014,

13 Estonia (emails: tea.tullus@emu.ee; reimo.lutter@emu.ee; hardi.tullus@emu.ee).

14 Corresponding author: Tiina Randlane, Department of Botany, Institute of Ecology and

15 Earth Sciences, University of Tartu, Lai 38-40, Tartu 51005, Estonia; email:

16 tiina.randlane@ut.ee; tel.: +372 7376232 
18 Abstract: Importance of single-species forest plantations in sustaining biodiversity

19 could be bigger than expected. We described the diversity of lichens and bryophytes in

2015 midterm (16-17-year-old) hybrid aspen (Populus tremula $\times$ P. tremuloides)

21 plantations in Estonia. Species richness and composition data were linked with

22 environmental and landscape-scale variables. Altogether, 44 lichen and 37 bryophyte

23 species were recorded from plantations; richnesses of bryophytes and lichens were

24 positively correlated. Lichen species composition was significantly affected by

25 landscape-scale parameters (distance to the nearest present forest, distance to the

26 nearest forest continuously occurring in the same place since 1930s, and forest area in

27 the study plot vicinity in 1930s). Bryophyte species composition was affected mainly by

28 light conditions and forest area in 1930s. Among lichens, functional group of sexual

29 crustose species dominated in midterm plantations; appearance of asexual lichens of

30 different growth forms is expected during next years. Our results indicate importance of

31 long-term availability of good-quality forests as sources of propagules. Short-rotation

32 hybrid aspen plantations can provide temporary habitats for forest species and thus in

33 part contribute to preserving landscape-scale biodiversity, if they are close to possible

34 colonisation sources. Green-tree retension in plantations will probably raise the

35 biodiversity value of those short-term communities.

36 Keywords: bryophytes, forest continuity, forest plantations, hybrid aspen, lichens 


\section{1. Introduction}

39 Forests are among the most important repositories of terrestrial biodiversity offering

40 diverse habitats for various groups of organisms. In northern Eurasia and North

41 America, the proportion of landscape covered by forests is currently (1990-2015)

42 considered stable or even expanding (Keenan et al. 2015), while the effects of intensive

43 forest management are still accompanied by a significant loss of forest biodiversity at all

44 levels, exhibiting decrease of genetic diversity, species richness and ecosystem

45 variability (Bernes et al. 2015). It has been suggested, that some negative impact of

46 forest management on the biodiversity can be reduced by harvesting timber not from

47 natural forests but from plantations of woody plants, considering that the sites chosen

48 for plantations are not habitats crucial to biodiversity (Hartmann et al. 2010).

49 Hybrid aspen (Populus tremula L. $\times$ P. tremuloides Michx.) is one of the fastest growing

50 trees in northern Europe, suitable for the production of pulp- and energy-wood (Tullus

51 et al. 2012a). This artificial cross is capable of growing faster and therefore shows

52 higher biomass productivity than its parent species during the first 20-30 years (Yu

53 2001) which is the recommended rotation period for this tree in northern Europe

54 (Tullus et al. 2012a). Both parent species are widely distributed in the world, P. tremula

55 in Eurasia, and P. tremuloides in North America. Currently, the area of hybrid aspen

56 plantations in Nordic and Baltic countries is estimated to cover ca 9000 ha (Tullus et al.

57 2015) and most of the plantations are established on the abandoned agricultural lands

58 (Soo et al. 2009a). Studies about the nutritional status of soil in first generation hybrid

59 aspen plantations on former agricultural fields revealed the decrease of soil reaction

$60(\mathrm{pH})$ but did not show significant depletion of primary macronutrients $(\mathrm{N}, \mathrm{P}, \mathrm{K})$ and soil

61 organic carbon (Lutter et al. 2016).

62 Forest plantations, especially single-species plantations, have earned a reputation of 
63 being "green deserts" due to unsuitable conditions for several species (Bremer and

64 Farley 2010). However, recent studies addressing biodiversity issues in relation to

65 forest plantations reveal controversial results, depending on the taxonomic group

66 considered, and characteristics of studied plantations, such as age of trees, light

67 conditions or previous agricultural land use (Felton et al. 2010). In general, biodiversity

68 is frequently found to be higher within tree plantations compared to agricultural

69 croplands, but clearly lower than that on native forest land (Stephens and Wagner

70 2007).

71 In hybrid aspen or other Populus plantations, biodiversity studies have dealt with

72 understorey vegetation of vascular plants and bryophytes (Weih et al. 2003; Soo et al.

$732009 a, 2009 b$; Tullus et al. 2012b, 2015). Previously, it has been shown that both

74 vascular plant and bryophyte diversity increased with increasing age of plantations, and

75 a slow succession towards a shade-tolerant understorey occurs in midterm plantations,

76 compared to young plantations. However, the number of species that appeared

77 characteristic of natural forests growing on similar soil types was low (Tullus et al.

78 2015). The parent species of hybrid aspen (Populus tremula and P. tremuloides) support

79 diverse epiphytic bryophyte communities, especially at older age (Kuusinen 1996;

80 Boudreault et al. 2000), while data about epiphytic bryophytes in hybrid aspen

81 plantations are scarce; e.g. nine bryophyte species have earlier been recorded as

82 growing only on hybrid aspen trunks (in addition to 19 species that inhabited both

83 ground and tree bases or trunks) (Tullus et al. 2015).

84 Lichen-forming fungi, another group of spore-producing organisms besides bryophytes,

85 form also a species rich component of the forest biota (Will-Wolf et al. 2002). European

86 aspen (Populus tremula) is frequently pointed out as a special substrate for a great

87 number of epiphytic lichens housing more host-tree-specific lichens than any other 
88 boreal tree species (Jüriado et al. 2003; Hedenås and Ericson 2004). The epiphytic

89 lichen communities on aspen differ significantly between early and late successional

90 forest stands and reach highest species richness values at the tree age of 80-100 yr

91 while on younger trees the richness values are clearly lower (Ellis and Ellis 2013); in

92 late successions a large number of cyanolichens characteristically occur on the basal

93 trunks of aspens (Kuusinen 1994; Hedenås and Ericson 2000). In addition to the

94 specific cyanobacterial lichens, the presence of Populus tremula individuals in forests

95 supports a multitude of common species and can remarkably increase the lichen

96 diversity of a stand (Jüriado et al. 2003). For example, 273 lichen species were recorded

97 as aspen epiphytes in Scotland (Ellis and Ellis 2013); 27 threatened (categories CR, EN,

98 VU and NT of the national red list according to Randlane et al. 2008) and altogether 120

99 lichen species were listed growing on aspen in Estonia (Marmor et al. 2017).

100 Considerbly less lichenized taxa (from 23 to 75) have been reported growing on

101 trembling aspen (Populus tremuloides) in different regions of North America (Sheard

102 and Jonescu 1974; Case 1977; Boudreault et al. 2000; Rogers and Ryel 2008). However,

103 all these data about aspen lichens are based on the studies performed in medium or old

104 natural stands of hybrid aspen parent species (Populus tremula and P. tremuloides)

105 while plantations of their hybrid have not been investigated in regard to lichen-forming

106 fungi.

107 In general, epiphytic lichen diversity is influenced by tree level, stand level and large

108 scale (e.g. climate, air pollution, landscape structure) effects. At the tree level,

109 occurrence of lichen species mainly depends on the physical (e.g. roughness, hardness

110 and water-holding capacity) and chemical properties (acidity) of the bark while forest

111 tree species composition, moisture regime and habitat light availability (tree density

112 and canopy cover) are considered the most influential factors for epiphytes at the stand 
113 level (Jüriado et al. 2009; Ellis 2012). In addition, landscape-scale factors such as forest

114 history, extent of woodlands, habitat fragmentation or connectivity have been used to

115 explain the epiphytic biodiversity (e.g. Fritz et al. 2009; Marmor et al. 2010; Ellis 2012).

116 These factors influence the community composition and richness mainly through the

117 dispersal properties of lichens and bryophytes (Ellis 2012), and in single-species

118 plantations, where tree- and stand-level factors vary little, they should play important

119 role in shaping the epiphytic communities.

120 Species responses to the changes in their ecosystems are currently often studied using

121 functional-trait-based approach (see review in Hevia et al. 2017). Species respond to

122 environmental conditions individualistically, using species' adaptive traits, however, the

123 response of many individual species comprising a community is scaled up to a complex

124 shift in compositional structure of the community; understanding the community

125 response to environmental or habitat change may be simplified through the search for

126 trait-based rules structuring community composition (Ellis and Coppins 2007a). Among

127 functional traits controlling successional trends of lichens, characters related to thallus

128 gross morphology, reproductive strategy, and lichen compounds have been mentioned.

129 The generally accepted succession of epiphytic lichens, considering functional traits,

130 starts with pioneer species which tend to be smaller and reproduce sexually by small

131 ascospores while late-successional competitive species tend to be larger, with a greater

132 investment in large vegetative diaspores and local establishment (Ellis 2012). Such

133 trait-based approach is considered useful not only for describing and understanding

134 community responses but also for conservation practices (e.g. Leppik et al. 2015) and

135 predicting changes in communities (Ellis and Coppins 2007a).

136 Improved knowledge about species diversity and succession of communities in single-

137 species forest plantations might help to understand the possible importance of these 
138 plantations in sustaining landscape-scale biodiversity. We aim to investigate the lichen 139 biota and bryophyte flora in the first generation midterm hybrid aspen plantations and 140 answer the following questions:

141 1. Do midterm hybrid aspen plantations support low or high species diversity of lichen142 forming fungi and bryophytes?

143 2. Which functional species groups dominate among lichens and bryophytes inhabiting 144 hybrid aspen plantations?

145 3. Which environmental and landscape factors influence the richness and composition 146 of lichens and bryophytes in hybrid aspen plantations?

147

148 2. Material and Methods

\section{$149 \quad 2.1$. Study sites}

150 The study was carried out in Estonia which is situated in Northern Europe, on the 151 eastern shores of the Baltic Sea. Estonia is lying in the moderate climate zone and in the 152 hemiboreal forest zone, a transitional zone between the boreal coniferous and 153 temperate deciduous forests. The 15 study sites were located in southern Estonia $154\left(57.752^{\circ} \mathrm{N}-58.590^{\circ} \mathrm{N}, 25.247^{\circ} \mathrm{E}-27.405^{\circ} \mathrm{E}\right)$ (Figure 1). The studied hybrid aspen 155 plantations were established in 1999 and 2000 on previous mineral agricultural soil, 156 using 1-year-old clonal micropropagated plants originating from Finland (Tullus et al. 157 2007). For site preparation, whole-area or strip ploughing had been carried out before 158 planting the trees to reduce competition between young seedlings and field layer. The 159 size of plantations varied from 0.7 to $32 \mathrm{ha}$, and the average planting density was 1300 160 trees per hectare. Permanent circular experimental plots, with an area of 0.1 ha and 161 with on average 106 aspens per plot, were established in 2003 and 2004 in hybrid 162 aspen plantations to monitor above-ground growth development and productivity of 
163 the trees (Tullus et al. 2007).

164

165

\subsection{Data collection}

166 Lichen and bryophyte data were collected during 2015 from 15 midterm (16- to 17-

167 year-old) hybrid aspen plantations, within squares of $10 \times 10 \mathrm{~m}$ in size (one square in

168 each plantation; squares located in the centre of the above-mentioned permanent

169 experimental plots). Squares were located in a typical part of the microrelief in

170 plantation and surrounded by a buffer plantation zone of at least 15 meters in order to

171 avoid the edge effect. The presence of all bryophyte and lichenized species was

172 recorded on all possible substrates within the established squares - on bark of hybrid

173 aspens (141 trees altogether in all studied plantations), and a few other young trees

174 (Betula sp. and Salix sp., occuring only rarely within the squares, with the maximum

175 height of $2 \mathrm{~m}$ ), dead wood (mainly on fallen twigs, but also a dead standing hybrid

176 aspen tree in one square) and ground. In every square, the abundance of each species

177 was estimated visually using a classical cover-abundance scale of $(+) 1-5$ where +

178 indicates one-two specimens recorded, with a small cover area; 1 - few specimens with

179 cover up to 5\%, 2 - any number, with cover 6-20\%, 3 - any number, with cover $21-$

$18050 \%, 4-$ any number, with cover 51-75\%, 5 - any number, with cover 76-100\%.

181 Specimens that were difficult to identify in the field were collected for later

182 determination. A stereomicroscope and light microscope were used for the

183 identification of taxa in the laboratory. In a few cases standardized thin-layer

184 chromatography (Orange et al. 2001) was applied to identify secondary compounds in

185 lichens. Nomenclature of lichenized taxa follows Randlane et al. (2016). Data on lichen

186 species frequency in Estonia were derived from Randlane and Saag (1999), the eSamba,

187 database of Estonian lichens (www.eseis.ut.ee), and the eBiodiversity database 
188 (http://elurikkus.ut.ee/). Lichenized taxa were grouped according to the ecological 189 indicator values of species by Wirth (2010). Nomenclature and frequency data of 190 bryophytes are according to Vellak et al. (2015). Bryophyte species were classified into

191 life strategy categories based on Dierssen (2001) and into groups according to the 192 ecological indicator values of taxa as specified by Düll (1991). The voucher specimens of 193 lichens are deposited in the lichenological herbarium of the Natural History Museum at 194 the University of Tartu (TU).

195 Different environmental characteristics were gathered from the permanent 196 experimental plots: soil properties during 2013-2014 according to the methods 197 described in Lutter et al. (2016), light data and measures of hybrid aspen trees in 2015, 198 in the middle of the growing season, according to Tullus et al. (2015). Additionally, for 199 each studied site we estimated landscape-scale factors: (a) a distance to nearest 200 currently present natural forest; (b) distance to the nearest natural forest that have 201 continuously occurred in the same locality for at least 75-80 years, and (c) historical 202 (1930s) and current (2000) cover of forest in the surrounding landscape. Distances to 203 natural forests were estimated by using recent (2015) aerial photos of Estonia, 204 provided by Estonian Land Board. Forest continuity was estimated by using historical 205 topographic maps (1:50,000) of the Estonian Land Board from 1935-1939 and 1969.

206 Historical and current forest cover was estimated by calculating the forest cover

207 persentage in the radius of $500 \mathrm{~m}$ around the study plots for 1930 s and in 2000 , 208 respectively. Habitat availability within radius of $500 \mathrm{~m}$ has been found to describe local 209 lichen and bryophyte diversity better than smaller or larger scales (Löbel et al. 2006). 210 All observed characteristics are listed in Table 1.

\section{$212 \quad$ 2.3. Statistical analyses}


213 Pearson correlation was used to link species richnesses of lichens and bryophytes. To

214 visualize the result, we used Type II (Major Axis) regression, R package "Imodel2",

215 function "lmodel2" (Legendre 2014) for obtaining trendline. Type II regression is not

216 dependent on the selection of $\mathrm{x}$ and $\mathrm{y}$ axis and can visualize correlative relationships.

217 For investigating the effect of environmental and landscape-scale factors (listed in Table

218 1) on diversity of lichens and bryophytes, we used linear regression models, $R$ function

219 "lm" (R Core Team 2016). As several variables were highly correlated (Table A1) and

220 could not be included to a single model, we used information-theoretic approach by

221 weighting models according to Akaike Information Criterion adjusted for small sample

222 size (AICc, Burnham and Anderson 2002). We used R package "MuMIn" (Barton 2016)

223 and function "dredge", as well as option "subset" which included to a single model only

224 dependent variables which were not strongly correlated $(|\mathrm{r}|<0.3)$. From all possible

225 models we considered these for which delta-AICc was $<2$, which is generally considered

226 as equally supported. We checked the spatial pattern of model residuals according to

227 Moran’s I, R package “ape”, function “Moran.I” (Paradis et al. 2005). No significant

228 spatial autocorrelation was detected. We also analysed separately diversity of sexual

229 and vegetative lichen groups.

230 To test, which environmental and landscape-scale variables influence the species

231 composition of lichens and bryophytes in aspen plantations, non-metric

232 multidimensional scaling (NMDS) ordination was applied. We used R package "vegan"

233 (Oksanen et al. 2013), function "metaMDS" and Bray-Curtis dissimilarities, based on the

234 species abundance data. The significance of $r^{2}$ of the regression model describing the

235 relationship between the given environmental or landscape-scale factor and the two

236 NMDS ordination axes scores was tested with a random permutation test (999

237 permutations), using the function "envfit". 
238 All variables were ln-transformed (except $\mathrm{pH}$ which is already in log-scale) prior

239 analyses, and all percentages or proportions were logit-transformed.

240

241 3. Results

\section{3.1. Diversity of lichens}

243 Altogether, 44 species of lichenized fungi were found in fifteen hybrid aspen plantations.

244 The majority of them were common taxa frequently recorded in Estonia, with the

245 exception of Arthonia patellulata, Athallia cerinella, Diplotomma pharcidium and

246 Leptorhaphis tremulae, which are known in less than ten localities in Estonia so far

247 (Table 2). One species, Candelariella lutella, was recorded for the first time nationally, in

24813 separate study plots of this research (Oja et al. 2016). The number of lichenized taxa

249 in study plots varied from 14 to 32 , and the mean number of lichen species in a plot was

250 25. The most frequent species were: Caloplaca cerina, Lecania naegelii, Lecanora

251 chlarotera and Xanthoria parietina (present in all plots), Candelariella lutella,

252 Gyalolechia flavorubescens, Lecania cyrtella, Lecanora sambuci, L. symmicta, Lecidella

253 euphorea, Phaeophyscia ciliata, Physcia adscendens, P. stellaris, and Physcia tenella

254 (present in $>80 \%$ of plots) (Table 2).

255 According to the substrate, 43 of the recorded species grew on trunks and branches of

256 trees, and one species, Peltigera rufescens, inhabited soil. Among the epiphytes, almost

257 all species were recorded on hybrid aspen, with the exception of Scoliciosporum

258 sarothamni which was found on a young Betula spp. only. Some species, e.g. Lecanora

259 carpinea, L. symmicta, Melanohalea olivacea and few others, were additionally recorded

260 from Betula spp. and Salix spp. (Table 2).

261 Evaluation of recorded taxa according to the characteristic traits of species revealed

262 some traits which were dominating. According to the growth form of the thallus, the 
263 species were divided between three main morphologies - species with crustose (59\%),

264 foliose (34\%) and fruticose (7\%) thalli (Table 2). In almost all recorded taxa photobiont

265 belonged to the group of coccoid green alga; lichens with cyanobacteria as photobiont

266 were not found; two fungi, Leptorhaphis tremula and Mycomicrothelia wallrothii, are

267 considered to be not lichenized (Smith et al. 2009). Among all recorded taxa, the

268 majority of the species (75\%) shared the strategy of reproducing sexually; of them the

269 two non-lichenized species, L. tremula and M. wallrothii, had perithecia while all the

270 other species had apothecia as fruiting bodies. All vegatatively reproducing species had

271 soredia as vegetative diaspores (Table 2); no taxa with isidia, phyllidia or other attached

272 vegetative propagules were found.

273 According to the ecological indicator values attributed to lichenized taxa (Wirth 2010),

274 the recorded species can be characterized by the following features: generally

275 preferring light, tolerating low or medium moisture, various values of substrate $\mathrm{pH}$

276 (between 4.1-4.8 and 6.6-7.5) and eutrophication (Table 2; Figure 2).

277

278 3.2. Diversity of bryophytes

279 Altogether, 37 bryophyte species were found in hybrid aspen plantations. In addition,

280 few specimens were identified at the genus level (Pellia sp. and Pohlia sp.). The majority

281 of the recorded taxa belonged to common species, with the exception of Leskea

282 polycarpa, Plagiomnium medium and Tortula truncata that are sporadically found in

283 Estonia (Table 3). The number of bryophyte species per study plot varied from 8 to 19

284 and the mean number of bryophyte species was 13. The most frequent species were

285 Amblystegium serpens, Brachythecium rutabulum, Oxyrrhynchium hians (in 100\% of

286 plots), Brachythecium salebrosum, Plagiomnium cuspidatum, and Sciuro-hypnum curtum

287 (present in $>80 \%$ of plots). 
288 According to the substrate, 21 species inhabited only the ground, 13 species were

289 recorded growing on the ground and on the trunks/tree bases of hybrid aspens, and

290 three species (Leskea polycarpa, Orthotrichum speciosum and Pylaisia polyantha) were

291 found only on trunks (Table 3). Seven bryophyte species were recorded, besides ground

292 and tree trunks, growing also on deadwood.

293 On the basis of life strategy categories according to Dierssen (2001), the bryophyte flora

294 of hybrid aspen plantations was dominated by competitive perennials (38\%), followed

295 by perennial stayers (24\%) and stress tolerant perennials (14\%), while the share of

296 short-living bryophyte species was small (Table 3).

297 According to the ecological indicator values attributed to bryophyte species (Düll 1991),

298 the recorded species can be characterized as generally preferring moderate to high light

299 and humidity levels and moderately acid pH of substrate (Figure 2).

300 Between the total species richnesses of bryophytes and lichens, a significant positive 301 correlation $(r=0.56, p=0.03)$ was revealed (Figure 3).

302

303 3.3. The effect of environmental and landscape-scale variables on lichen and

304 bryophyte biota in hybrid aspen plantations

305 Species richnesses of lichens and bryophytes in hybrid aspen plantations increased with

306 historical forest cover around the study plot in 1930s, and bryophyte richness

307 additionally increased with the density of trees in the study plot (Table 4, Figure 4). The

308 positive effect of historical forest cover was significant both for diversity of sexual and

309 vegetative lichens $(t=2.6, p=0.02$, and $t=2.2, p=0.04$, respectively).

310 Effect of environmental and landscape-scale variables on species composition of lichens

311 and bryophytes was studied by using NMDS ordination. Lichen species composition was

312 significantly and strongly influenced by landscape-scale variables: distance from 
313 currently present nearest forest, distance from continuously occurring forest and

314 historical forest cover in the surroundings. At the same time, variables linked with soil

315 and light conditions or tree characteristics did not significantly influence the variation

316 of lichen species composition (Table 5, Figure 5). Bryophyte species composition was

317 significantly affected by the phosphorus content in soil, by canopy openness and

318 amount of canopy-transmitted solar radiation (Table 5, Figure 6). Similarly to lichens,

319 historical (in 1930s) forest cover in the surrounding landscape had significant effect on

320 the variation of bryophyte species composition.

321

322 4. Discussion

323 4.1. Species diversity of lichens and bryophytes in midterm hybrid aspen

\section{4 plantations}

325 Single-species forest plantations are generally considered habitats with low number of

326 inhabiting species (Bremer and Farley 2010). We detected 44 lichen and 37 bryophyte

327 species in fifteen studied hybrid aspen plantations, with 25 species of lichens and 13

328 bryophytes in average per plot of $100 \mathrm{~m} 2$ size (Tables 2 and 3). One of the parent

329 species of hybrid aspen, Populus tremula, is widely known to support high diversity of

330 epiphytes at the medium tree age; e.g. Ellis and Ellis (2013) recorded 139 lichen species

331 from 40 aspen trees which age varied from 27 to $165 \mathrm{yrs}$, with a mean of $80 \mathrm{yrs}$.

332 However, stands of young (less than $20 \mathrm{yr}$ ) aspens have only rarely been investigated in

333 regard to lichen-forming fungi. Davies et al. (2014) reported 23 epiphytc lichen species

334 and three bryophytes on 15-year-old aspens grown at two experimental sites in

335 Scotland. Compared with these data, the species richness of lichens and mosses in

336 midterm (16- to 17-year-old) plantations of hybrid aspen was remarkable. 
337 Strong positive correlation between lichen and bryophyte species richnesses (Figure 3)

338 indicates that the diversity of two groups are influenced by similar factors. An opposite 339 relationship, the negative association between the species numbers of lichens and 340 mosses growing on the same substrate, has been earlier demonstrated in epiphytic 341 communities (e.g. Löbel et al. 2006; Degtjarenko et al. 2016). In our study, almost all

342 lichens (except one, Peltigera rufescens) inhabited trunks and branches of aspens and

343 few other young trees (mainly Betula spp.) while majority of bryophytes (34 species out 344 of 37) were recorded growing on ground. The lack of lichens on ground in hybrid aspen 345 plantations is probably due to the absence of the available free substrate as ground 346 lichens are generally poor competitors with faster growing ground-dwelling vascular 347 plants and the more vigorous bryophytes (Gilbert 1993). The lack of mosses on trees 348 could be connected with time factor and also with the current light and moisture 349 conditions on the trunks of young aspens since epiphytic lichens generally dominate 350 over mosses in drier and lighter niches on trees (Sales et al. 2016). The other potential 351 substrates for these groups of organisms were limited as the amount of deadwood was 352 small in the studied stands and any kind of rocks or boulders were not available 353 because the plantations had been established on abondoned agricultural lands, crop

354 fields or grassland (Tullus et al. 2007), where erratic boulders and other stones were 355 obviously cleared on purpose.

356 The majority of both lichens and bryophytes recorded in studied plantations were 357 common species (Tables 2 and 3). Although one lichenized fungus, Candelariella lutella, 358 was recorded for the first time nationally, it is probably not rare in Estonia but has been 359 overlooked due to its very small size (Oja et al. 2016). In general, aspen epiphytes 360 include only a small number of specialist lichen species (e.g. Arthonia patellulata and 361 Lecanora populicola), which are known only from aspen, in addition to numerous 
362 common species associated with more nutrient-rich bark conditions (Lewis and Ellis

363 2010). Our results are in accordance with these findings (Table 2). The so-called

364 nationally valuable, i.e. protected, threatened or rare species with up to 10 localities in

365 Estonia, were not recorded among bryophytes, while a few species belonging currently

366 to the rare taxa were found among lichens.

367

368

4.2. Functional species groups among lichens and bryophytes in studied

369 plantations

370 We used functional-trait-based approach of species' groups to describe the current stage of lichen successions in midterm hybrid aspen plantations; functional groups related to thallus gross morphology and reproductive strategy (Ellis and Coppins 2007a) were applied. Among lichens, functional group of sexually reproducing crustose species formed the most numerous group (25 taxa, Table 2); such species (e.g. Athallia pyracea, Lecania naegelii, Lecanora carpinea, L. chlarotera, L. populicola, Lecidella elaeochroma etc.) are considered early colonists of aspen bark, becoming less abundant as the tree ages, and are replaced progressively by asexually reproducing crustose lichens, foliose lichens and bryophytes on mid-aged trees (Ellis and Ellis 2013). Higher

379 frequencies of crustose lichens on younger trees are considered indicative of an open bark community, characterized by lower levels of competition for space and light (Ellis and Coppins 2006). In addition, we recorded one vegetatively reproducing crustose

382 lichen, Scoliciosporum sarothamni, 15 foliose species, both sexually and asexually

383 reproducing, and three asexual fruticose species in studied midterm plantations (Table 384 2). We also found 16 bryophyte species growing on the trees, but only three of them 385 inhabited explicitly tree trunks. Among all recorded bryophytes, species with different 386 life strategies were present, but perennials, including competitive and stress tolerant 
387 perennials, dominated (Table 3). These data indicate that hybrid aspens growing in

388 midterm plantations provide substrate to lichen species from other functional groups

389 besides pioneers - sexual crustose taxa - and also to some bryophytes, already at the

390 tree age of $16-17$ years.

391 According to the ecological indicator values that are ascribed to lichen (Wirth 2010) and

392 bryophyte species (Düll 1991), the two groups of spore-producing organisms found in

393 hybrid aspen plantations showed some differences: compared to bryophytes, lichen

394 species preferred stronger light, lower humidity and higher temperature levels (Figure

395 2). Both groups tolerated various values of substrate $\mathrm{pH}$, and lichens also various

396 eutrophication levels (data for bryophytes not available). These differences in ecological

397 preferences of the two groups are explained by the fact that they generally inhabited

398 different substrates in studied plantations - recorded lichen species were mostly

399 epiphytic (with one exception), and bryophytes were mainly epigeic, growing on the

400 ground (Tables 2 and 3) where light was evidently less and moisture more available

401 than on aspen trunks.

\subsection{Factors affecting species diversity of lichens and bryophytes}

404 We used linear modeling and NMDS ordination to study the effects of several 405 environmental and landscape variables on lichen and bryophyte species richnesses and compositions in hybrid aspen plantations. None of the studied environmental factors

407 had significant effect on lichen diversity measures. Richness of bryophytes was

408 positively correlated with tree density on study plot (Figure 4), and bryophyte species composition was significantly affected by the environmental parameters connected to

410 the light conditions - the amount of canopy-transmitted solar radiation and canopy

411 openness (Table 5, Figure 6). Although bryophytes are generally regarded as shade 
412 plants, there is a wide range in the light responses of different bryophyte species

413 (Marshall and Proctor 2004). The bryoflora of the current study also contained species

414 with variable light preferences, ranging from shade tolerant species (with light index 3)

415 to light-demanding species (with light index 8) (Figure 2). Like in young (7- to 8-year-

416 old) hybrid aspen plantations (Tullus et al. 2012b), the share of light-preferring species,

417 typical of open grassland communities, was continuously high in midterm plantations

418 as the species with light indices 5-7 formed the most numerous group (Figure 2).

419 Most tested landscape-scale factors strongly influenced the richness and composition of

420 lichens and bryophytes. Only current forest cover in the plot surroundings did not have

421 any effect on studied biodiversity elements. Forest cover in the surroundings of study

422 plot in 1930s strongly determined the richness of both bryophytes and lichens (Figure

423 4), including the richness of sexual as well as vegetative lichen taxa. Distance from study

424 plot to the nearest contemporary forest, and the distance from study plot to the nearest

425 continuously occurring forest affected significantly the variation of lichen species

426 composition (Table 5, Figure 5). These results indicate the importance of landscape

427 structure and quality on species colonisation patterns. First colonizers among epiphytes,

428 sexual crustose lichens, are characterized by long-range dispersal via ascospores while

429 both vegetative propagules of lichens (Dettki and Esseen 2003) and large fraction of

430 bryophyte diaspores (Sundberg 2005) are suitable for short distance dispersal. This is

431 explained by the fact that sexual diaspores commonly are distinctly smaller than

432 asexual, and thus seem to fit to a ruderal strategy of dispersal over longer distances,

433 including between unoccupied patches (Calviño-Cancela et al. 2013). In our study, the

434 distances from study plot to closest forest remained between 35 and $670 \mathrm{~m}$ (Table 1).

435 Various values of the effective dispersal distance for asexual lichens are suggested, but

436 generally they remain within a few hundreds of meters (Walser 2004). For example, for 
437 an epiphytic foliose lichen Lobaria pulmonaria, the maximum dispersal ranges 30-75 m

438 for vegetative propagation by isidioid soredia and thallus fragments have been reported

439 (Öckinger et al. 2005; Jüriado et al. 2011). However, it is commonly accepted that

440 extreme events, like wind storms, or long-distance vectors, like birds, may carry not

441 only the light sexual propagules, but also the heavier vegetative propagules of lichens,

442 several hundreds of meters (Walser 2004). Therefore it is not impossible that asexual

443 lichen species would colonize the trees in plantations located farther from the closest

444 forest than the generally accepted effective dispersal distance of these species, but the

445 process may need time. Bryophytes, in general, are considered to have high potential for

446 generative and vegetative propagation, being able to disperse long-distance (Frahm

447 2008). Though, on smaller spatial scale, many bryophyte species may be dispersal

448 limited (Snäll et al. 2003; Kimmerer 2005), emphasizing the importance of vicinitiy to

449 propagule sources. Adjacent land-use and high structural connectivity of landscape has

450 been shown to be highly important in determining the community development in

451 young or restored forests (Crouzeilles and Curran 2016).

452 Furthermore, our results demonstrated that not only distance from closest forest was

453 vital for the dispersal of lichens and bryophytes, but also the forest quality, i.e. its area

454 and ecological continuity. A study by Marmor et al. (2011) in the coniferous forests in

455 Estonia revealed that forest continuity was the most important variable explaining the

456 number of epiphytic lichen species at the forest stand scale. The significant effect of

457 forest continuity on the lichen species richness has been related both to the low

458 dispersal capacity and to the specific microhabitat or substrate preferences of several

459 species. Similarly to our results, the strong effect of forest history on lichen biota has

460 been described by Ellis and Coppins (2007b) who showed that species richness was

461 better explained by historic woodland structure compared to the present one. Effect of 
462 historical forest cover on current species richness indicates possible time-lags in the 463 landscape (Kuussaari et al. 2009). Species extinctions take time and historically larger

464 and better connected forests still likely have higher richness of lichens and bryophytes

465 in the remaining habitat patches, thus also influencing the colonisation patterns of

466 nearby plantations. Epiphytic lichens and bryophytes can have considerably delayed

467 responses to changes in environmnetal conditions or landscape structure due to low

468 rates of extinction (Snall et al. 2004, Johansson et al. 2013a). For example, Johansson et

469 al. (2013b) showed that habitat connectivity (density of oak trees) of almost 180 years

470 ago determined the current occurrence of epiphytic lichens in Swedish landscapes. It is

471 additionally possible, that in continuously occurring and historically larger forests,

472 extant lichen and bryophyte populations are still larger, genetically more diverse and

473 more viable, providing also more propagules for establishing new populations

474 (Scheidegger \& Silke 2009, Jüriado et al. 2011). Such time-lags can also provide

475 conservation opportunity - in landscapes where historically large forest habitats have

476 harboured high diversity of lichens and bryophytes, increase in forest cover can help to

477 avoid possible future extinctions by enhancing functional connectivity between

478 populations and increasing metapopulation size (Johansson et al. 2013a). Our results

479 show that even short-rotation hybrid aspen plantations can in part contribute to

480 mitigating the effects of habitat loss and fragmentation, but only if they are close to

481 possible colonisation sources.

482 To conclude, hybrid aspen plantations support remarkable species diversity of lichen-

483 forming fungi as well as bryophytes already at such young age as 16-17 years. The

484 predicted felling age of hybrid aspen is less than 30 years (Tullus et al. 2012a), thus an

485 increase in species richness of both studied groups can be expected during the next

486 dozen or more years, considering that the increasing diameter of tree stems and stumps 
487 left after harvest will provide new habitats for bryophytes and lichens (Tullus et al.

$4882012 b$ ). This assumption is in accordance with recently described unimodal trend in species richness on European aspen revealing the addition of species to a lichen community during an earlier phase of tree growth (20-80 yr), with a peak (80-100 yr) and subsequent loss of species from a community during a later phase of tree growth

492 (>100 yr) (Ellis and Ellis 2013). It can also be assumed that the current successional 493 stage of epiphytic lichen communities in studied plantations, that is composed mainly of sexual crustose species, will change during the following years and more asexual species, both crustose, foliose and fruticose, will inhabit the trees since greater competitive ability of asexual lichens in establishment within more crowded microhabitats has been suggested (Ellis and Coppins 2007a). Similar results were received in the eucalypt plantations of different ages in Spain where crustose lichens with sexual reproduction were especially linked to young and intermediate stages, whereas asexual

500 lichens were more frequently recorded in later stage (Calviño-Cancela et al. 2013). But

501 in contrary to eucalypt plantations, where lichen species richness and abundance

502 remained low also in mature stands, hybrid aspen plantations may achieve some 503 ecological value at their later ages. In regions where historical forests areas are present 504 and nearby, hybrid aspen plantations can increase functional connectivity for number of 505 lichen and bryophyte species and provide support for preservation of landscape-scale 506 biodiversity. To additionally increase the effectiveness of hybrid aspen plantations, 507 green-tree retention in hybrid aspen plantations should be considered as recommended 508 for native aspen forests (Hazell and Gustafsson 1999; Rosenvald and Lõhmus 2008). In 509 the case of leaving retention trees in plantations, the planted stands may act not only as 510 sink habitats which the species can colonize and where they can survive until felling, 511 but also as surviving points after cutting majority of trees, and where from the species 
512 can disperse further from the plantation area. Green-tree retent,ion in hybrid aspen

513 plantations will probably raise the overall biodiversity value of these short-term

514 plantations. However, it is not currently known which lichen and bryophyte species

515 really are able to colonize the hybrid aspens by their felling age, and thus further

516 studies of epiphytic communities in hybrid aspen plantations should be performed

517 before their clear-cut.

518

519 Acknowlegements

520 The study has been financed by the Estonian State Forest Management Centre through

521 the project "Smart biodiversity conservation in Estonian natural and managed forests:

522 ecoinformatical solutions in a case-study in southern Estonia" to MP, by the Estonian

523 Research Council through the personal research funding (PUT1017 to TR) and

524 institutional research fundings (IUT14-29, IUT21-4 and IUT34-9), and by the European

525 Regional Development Fund (Centre of Excellence EcolChange). Two anonymous

526 reviewers are thanked for valuable comments, and Ede Oja is acknowledged for the help

527 in identification of some Lecanora species.

528

529 References

530 Barton, K. 2016. MuMIn: Multi-Model Inference. R package version 1.15.6.

531 https://CRAN.R-project.org/package=MuMIn

532 Berglund, H., and Jonsson, B.G. 2005. Verifying an extinction debt among lichens and

533 fungi in northern Swedish boreal forests. Conserv. Biol. 24: 338-348.

534 doi:10.1111/j.1523-1739.2005.00550.x.

535 Bernes, C., Jonsson, B.G., Junninen, K., Lõhmus, A., Macdonald, E., Müller, J., and

536 Sandström, J. 2015. What is the impact of active management on biodiversity in 
537 boreal and temperate forests set aside for conservation or restoration? A systematic 538 map. Environ. Evid. 4(25): 1-22, s13750-015-0050-7.

539 Bremer, L.L., and Farley, K.A. 2010. Does plantation forestry restore biodiversity or 540 create green deserts? A synthesis of the effects of land-use transitions on plant

541 species richness. Biodivers. Conserv. 19: 3893-3915. doi:10.1007/s10531-010-

$5429936-4$.

543 Boudreault, C., Gauthier, S., and Bergeron, Y. 2000. Epiphytic lichens and bryophytes on

544 Populus tremuloides along a chronosequence in the southwestern boreal forest of

545 Québec, Canada. Bryologist 103(4): 725-738. doi:10.1639/0007-

$546 \quad 2745(2000) 103[0725: E L A B O P] 2.0 . C O ; 2$.

547 Burnham, K.P., and Anderson, D.R. 2002. Model Selection and Multi-Model Inference. A

548 Practical Information-Theoretic Approach. Springer Verlag, New York.

549 Calviño-Cancela, M., López de Silanes, M.E., Rubido-Bará, M., and Uribarri, J. 2013. The

550 potential role of tree plantations in providing habitat for lichen epiphytes. For. Ecol.

$551 \quad$ Manage. 291: 386-395. doi:10.1016/j.foreco.2012.11.023.

552 Case, J.W. 1977. Lichens on Populus tremuloides in Western Central Alberta, Canada.

$553 \quad$ Bryologist 80: 48-70. doi:10.2307/3242510.

554 Crouzeilles, R., and Curran, M. 2016. Which landscape size best predict the influence of

555 forest cover on restoration success? A global meta-analysis on the scale of effect. J.

556 Appl. Ecol. 53: 440-448. doi: 10.1111/1365-2664.12590

557 Davies, C., Ellis, C.J., Iason, G.R., and Ennos, R.A. 2014. Genotypic variation in a

558 foundation tree (Populus tremula L.) explains community structure of associated

559 epiphytes. Biol. Lett. 10: 20140190. doi:10.1098/rsbl.2014.0190. 
560 Degtjarenko, P., Marmor, L., and Randlane, T. 2016. Changes in bryophyte and lichen

561 communities on Scots pines along an alkaline dust pollution gradient. Environ. Sci. .

562 Pollut. Res. 23: 17413-17425. doi:10.1007/s11356-016-6933-5.

563 Dettki, H., and Esseen, P.A. 2003. Modelling long-term effects of forest management on

564 epiphytic lichens in northern Sweden. For. Ecol. Manage. 175: 223-238.

565 doi:10.1016/S0378-1127(02)00131-7.

566 Dierssen, K. 2001. Distribution, ecological amplitude and phytosociological

567 characterization of European bryophytes. Bryophytorum Bibliotheca, Band 56.

568 Berlin, Stuttgart.

569 Düll, R. 1991. Zeigewerte von Laub- und Lebermoosen. Scripta Geobotanica 18: 175-

$570 \quad 215$.

571 eBiodiversity database. Available from http://elurikkus.ut.ee/ [accessed 12 December 572 2016].

573 Ellis, C.J. 2012. Lichen epiphyte diversity: a species, community and trait-based review.

574 Perspect. Plant Ecol. Evol. Syst. 14: 131-152. doi:10.1016/j.ppees.2011.10.001.

575 Ellis, C.J., and Coppins, B.J. 2006. Contrasting functional traits maintain lichen epiphyte

576 diversity in response to climate and autogenic succession. J. Biogeogr. 33: 1643-

577 1656. doi:10.1111/j.1365-2699.2006.01522.x.

578 Ellis, C.J., and Coppins, B.J. 2007a. Reproductive strategy and the compositional

579 dynamics of crustose lichen communities on aspen (Populus tremula L.) in Scotland.

$580 \quad$ Lichenologist 39(4): 377-391. doi:10.1017/S0024282907006937.

581 Ellis, C.J., and Coppins, B.J. 2007b. 19th century woodland structure controls stand-

582 scale epiphyte diversity in present-day Scotland. Divers. Distrib. 13: 84-91.

583 doi:10.1111/j.1366-9516.2006.00310.x. 
584 Ellis C.J., and Ellis S.C. 2013. Signatures of autogenic epiphyte succession for an aspen 585 chronosequence. J. Veg. Sci. 24: 688-701. doi:10.1111/j.1654-1103.2012.01492.x. 586 eSamba. Database of Estonian lichens. Available from http://www.eseis.ut.ee [accessed $587 \quad 12.12 .2016]$.

588 Felton, A., Knight, E., Wood, J., Zammit, C., and Lindenmayer, D. 2010. A meta-analysis of 589 fauna and flora species richness and abundance in plantations and pasture lands. Biol. 590 Conserv. 143: 545-554. doi:10.1016/j.biocon.2009.11.030.

591 Frahm, J.P. 2008. Diversity, dispersal and biogeography of bryophytes (mosses).

592 Biodivers. Conserv .17:277-284. doi:10.1007/s10531-007-9251-x.

593 Fritz, Ö., Niklasson, M., and Churski, M. 2009. Tree age is a key factor for the 594 conservation of epiphytic lichens and bryophytes in beech forests. Appl. Veg. Sci. 12: 595 93-106. doi:10.1111/j.1654-109X.2009.01007.x.

596 Gilbert, O.L. 1993. The lichens of chalk grassland. Lichenologist 25: 379-414.

597 doi:10.1017/S0024282993000477.

598 Hartmann, H., Daoust, G., Bigué, B., and Messier, C. 2010. Negative or positive effects of 599 plantation and intensive forestry on biodiversity: A matter of scale and perspective. $600 \quad$ Forestry Chronicle 86: 354-364. doi:10.5558/tfc86354-3.

601 Hazell, P., and Gustafsson, L. 1999. Retention of trees at final harvest-evaluation of a 602 conservation technique using epiphytic bryophyte and lichen transplants. Biol.

603 Conserv. 90: 133-142. doi:10.1016/S0006-3207(99)00024-5.

604 Hedenås, H., and Ericson, L. 2000. Epiphytic macrolichens as conservation indicators:

605 successional sequence in Populus tremula stands. Biol. Conserv. 93: 43-53.

606 doi:10.1016/S0006-3207(99)00113-5. 
607 Hedenås, H., and Ericson, L. 2004. Aspen lichens in agricultural and forest landscapes:

608 the importance of habitat quality. Ecography 27: 521-531. doi:10.1111/j.0906-

$609 \quad 7590.2004 .03866 . x$.

610 Hevia, V., Martín-López, B., Palomo, S., García-Llorente, M., deBello, F., and Gonzáles, J.A.

611 2017. Trait-based approaches to analyze links between the drivers of change and

612 ecosystem services: Synthesizing existing evidence and future challenges. Ecol. Evol.

$613 \quad 7(3): 831-844$. doi:10.1002/ece3.2692.

614 Johansson, V., Ranius, T., and Snäll, T. 2013a. Epiphyte metapopulation persistence after

615 drastic habitat decline and low tree regeneration: time-lags and effects of

616 conservation actions. J. Appl. Ecol. 50(2): 414-422.

617 Johansson, V., Snäll, T., and Ranius, T. 2013b. Estimates of connectivity reveal non-

618 equilibrium epiphyte occurrence patterns almost 180 years after habitat decline.

619 Oecologia 172(2): 607-615.

620 Jüriado, I., Liira, J., Csencsics, D., Widmer, I., Adolf, C., Kohv, K., and Scheidegger, C. 2011.

621 Dispersal ecology of the endangered woodland lichen Lobaria pulmonaria in

622 managed hemiboreal forest landscape. Biodivers. Conserv. 20: 1803-1819.

623 doi:10.1007/s10531-011-0062-8.

624 Jüriado, I., Liira, J., and Paal, J. 2009. Diversity of epiphytic lichens in boreo-nemoral

625 forests on the North-Estonian limestone escarpment: the effect of tree level factors

626 and local environmental conditions. Lichenologist 41: 81-96.

627 doi:10.1017/S0024282909007889.

628 Jüriado, I., Paal, J., and Liira, J. 2003. Epiphytic and epixylic lichen species diversity in

629 Estonian natural forests. Biodivers. Conserv. 12: 1587-1607.

630 doi:10.1023/A:1023645730446. 
631 Keenan, R.J., Reams, G.A., Achard, F., de Freitas, J.V., Grainger, A., and Lindquist, E. 2015. 632 Dynamics of global forest area: results from the FAO Global Forest Resources 633 Assessment 2015. For. Ecol. Manage. 352: 9-20. doi:10.1016/j.foreco.2015.06.014. 634 Kimmerer, R.W. 2005. Patterns of dispersal and establishment of bryophytes colonizing 635 natural and experimental treefall mounds in northern hardwood forests. Bryologist 636 108(3): 391-401.

637 Kuusinen, M. 1994. Epiphytic lichen flora and diversity on Populus tremula in old638 growth and managed forests of southern and middle boreal Finland. Ann. Bot. Fen.

$639 \quad 31: 245-260$.

640 Kuusinen, M. 1996. Epiphyte flora and diversity on basal trunks of six old-growth forest 641 tree species in southern and middle boreal Finland. Lichenologist. 28(5): 443-463. 642 doi: $10.1006 /$ lich.1996.0043.

643 Kuussaari, M., Bommarco, R., Heikkinen, R. K., Helm, A., Krauss, J., Lindborg, R., Öckinger, 644 E., Pärtel, M., Pino, J., Rodà, F., and Stefanescu, C., 2009. Extinction debt: a challenge 645 for biodiversity conservation. Trends Ecol. Evol. 24(10): 564-571.

646 Legendre, P. 2014. lmodel2: Model II Regression. R package version 1.7-2.

647 https://CRAN.R-project.org/package=lmodel2

648 Leppik, E., Jüriado, I., Suija, A., and Liira, J. 2015. Functional ecology of rare and common 649 epigeic lichens in alvar grasslands. Fung. Ecol. 13: 66-76.

650 doi:10.1016/j.funeco.2014.08.003.

651 Lewis, J.E.J., and Ellis, C.J. 2010. Taxon compared to trait-based analysis of epiphytes, 652 and the role of tree species and tree age in community composition. Plant Ecol.

653 Divers. 3: 203-210. doi:10.1080/17550874.2010.505966. 
654 Löbel, S., Snäll, T., and Rydin, H. 2006. Species richness patterns and metapopulation 655 processes - evidence from epiphyte communities in boreo-nemoral forests.

656 Ecography 29: 169-182. doi:10.1111/j.2006.0906-7590.04348.x.

657 Lutter, R., Tullus, A., Kanal, A., Tullus, T., and Tullus, H. 2016. The impact of short-

658 rotation hybrid aspen (Populus tremula L. $\times$ P. tremuloides Michx.) plantations on

659 nutritional status of former arable soils. For. Ecol. Manage. 362: 184-193.

660 doi:10.1016/j.foreco.2015.12.009.

661 Marmor, L., Tõrra, T., and Randlane, T. 2010. The vertical gradient of bark pH and

662 epiphytic macrolichen biota in relation to alkaline air pollution. Ecol. Indic. 10: 1137-

663 1143. doi:10.1016/j.ecolind.2010.03.013.

664 Marmor, L., Tõrra, T., Saag, L., and Randlane, T. 2011. Effects of forest continuity and

665 tree age on epiphytic lichen biota in coniferous forests in Estonia. Ecol. Indic. 11:

666 1270-1276. doi:10.1016/j.ecolind.2011.01.009.

667 Marmor, L., Randlane, T., Jüriado, I., and Saag, A. 2017. Host tree preferences of red-

668 listed epiphytic lichens in Estonia. Baltic Forestry 23(2): 364-373.

669 Marshall, M., and Proctor, M.C.F. 2004. Are bryophytes shade plants? Photosynthetic

670 light responses and proportions of chlorophyll a, chlorophyll b and total carotenoids.

671 Ann. Bot. 94: 593-603. doi:10.1093/aob/mch178.

672 Öckinger, E., Niklasson, M., and Nilsson, S.G. 2005. Is local distribution of the epiphytic

673 lichen Lobaria pulmonaria limited by dispersal capacity or habitat quality? Biodivers.

674 Conserv. 14: 759-773. doi:10.1007/s10531-004-4535-X.

675 Oja, E., Gerasimova, J., Suija, A., Lõhmus, P., and Randlane, T. 2016. New Estonian

676 records and amendments: Lichenized fungi. Folia Cryptog. Estonica 53: 123-126.

677 doi:10.12697/fce.2016.53.14. 
678 Oksanen, J., Blanchet, F.G., Kindt, R., Legendre, P., Minchin, P.R., O'Hara, R.B., Simpson, 679 G.L., Solymos, P., Stevens, M.H.H., and Wagner, H. 2013. Vegan: Community Ecology 680 Package. R package version 2.0-10. Available from http://CRAN.R681 project.org/package=vegan.

682 Orange, A., James, P.W., and White, F.J. 2001. Microchemical methods for the 683 identification of lichens. British Lichen Society.

684 Paradis, E., Claude, J., and Strimmer, K. 2004. APE: analyses of phylogenetics and 685 evolution in R language. Bioinformatics 20: 289-290.

686 Randlane, T., and Saag, A. (editors) 1999. Second checklist of lichenized, lichenicolous 687 and allied fungi of Estonia. Folia Cryptog. Estonica 35: 1-132.

688 Randlane, T., Jüriado, I., Suija, A., Lõhmus, P., and Leppik, E. 2008. Lichens in the new 689 Red List of Estonia. Folia Cryptog. Estonica 44: 113-120.

690 Randlane, T., Saag, A., and Suija, A. 2016. Lichenized, lichenicolous and allied fungi of 691 Estonia. Ver. Dec 31, 2016. http://esamba.bo.bg.ut.ee/ checklist/est/home.php $692 \quad$ [accessed 12 January 2017].

693 Ranius, T., Eliasson, P., and Johansson, P. 2008. Large-scale occurrence patterns of red694 listed lichens and fungi on olad oaks are influenced both by current and historical 695 habitat density. Biodivers. Conserv. 17: 2371-2381. doi:10.1007/s10531-008-9387-3.

696 R Core Team 2016. R: A language and environment for statistical computing. R

697 Foundation for Statistical Computing, Vienna, Austria. https://www.R-project.org/ 698 Rogers, P.C., and Ryel, R.J. 2008. Lichen community change in response to succession in 699 aspen forests of the southern Rocky Mountains. For. Ecol. Manage. 256: 1760-1770. 700 doi:10.1016/j.foreco.2008.05.043. 
701 Rosenvald, R., and Lõhmus, A. 2008. For what, when, and where is green-tree retention

702 better than clear-cutting? A review of the biodiversity aspects. Forest Ecology and

703 Management 255:1-15.

704 Sales, K., Kerr, L., and Gardner, J. 2016. Factors influencing epiphytic moss and lichen

705 distribution within Killarney National Park [online]. Bioscience Horizons 9: hzw008.

706 doi:10.1093/biohorizons/hzw008.

707 Sheard, J.W., and Jonescu, M.E. 1974. A multivariate analysis of the distribution of

708 lichens on Populus tremuloides in western-central Canada. Bryologist 77: 514-530.

709 Smith, C.W., Aptroot, A., Coppins, B.J., Fletcher, A., Gilbert, O.L., James, P.W., and Wolseley,

710 P. 2009. The Lichens of Great Britain and Ireland. The British Lichen Society, London.

711 Snäll, T., Ribeiro Jr., P.J., and Rydin, H. 2003. Spatial occurrence and colonisations in

712 patch-tracking metapopulations: local conditions versus dispersal. Oikos 103(3):

$713 \quad 566-578$.

714 Snäll, T., Hagström, A., Rudolphi, J., and Rydin, H. 2004. Distribution pattern of the

715 epiphyte Neckera pennata on three spatial scales - importance of past landscape

716 structure, connectivity and local conditions. Ecography 27: 757-766.

717 Soo, T., Tullus, A., Tullus, H., and Roosaluste, E. 2009a. Floristic diversity responses in

718 young hybrid aspen plantations to land-use history and site preparation treatments.

719 For. Ecol. Manage. 257: 858-867. doi:10.1016/j.foreco.2008.10.018.

720 Soo, T., Tullus, A., Tullus, H., Roosaluste, E., and Vares, A. 2009b. Change from agriculture

721 to forestry: floristic diversity in young fast-growing deciduous plantations on former

722 agricultural land in Estonia. Ann. Bot. Fenn. 46: 353-364. doi:10.5735/085.046.0410.

723 Stephens, S.S., and Wagner, M.R. 2007. Forest plantations and biodiversity: a fresh

724 perspective. J. For. 105: 307-313. 
725 Sundberg, S. 2005. Sporophyte size positively influences short-range spore dispersal in

726 Sphagnum, but what happens further away? Oikos 108: 115-124.

727 doi:10.1111/j.0030-1299.2005.12916.x.

728 Tullus, A., Tullus, H., Vares, A., and Kanal, A. 2007. Early growth of hybrid aspen (Populus

729 tremula L. x P. tremuloides Michx.) plantations on former agricultural lands in Estonia.

$730 \quad$ For. Ecol. Manage. 245: 118-129. doi:10.1016/j.foreco.2007.04.006.

731 Tullus, A., Rytter, L., Tullus, T., Weih, M., and Tullus, H. 2012a. Short-rotation forestry

732 with hybrid aspen (P. tremula L. $\times$ P. tremuloides Michx.) in Northern Europe. Scand. J.

$733 \quad$ For. Res. 27: 10-29. doi:10.1080/02827581.2011.628949.

734 Tullus, T., Tullus, A., Roosaluste, E., Lutter, R., and Tullus, H. 2015. Vascular plant and

735 bryophyte flora in midterm hybrid aspen plantations on abandoned agricultural land.

736 Can. J. For. Res. 45: 1183-1191. doi:10.1139/cjfr-2014-0464.

737 Tullus, T., Tullus, A., Roosaluste, E., and Tullus, H. 2012b. Bryophyte vegetation in young

738 deciduous forest plantations. Baltic Forestry 18(2): 205-2013.

739 Vellak, K., Ingerpuu, N., Leis, M., and Ehrlich, L. 2015. Annotated checklist of Estonian

$740 \quad$ bryophytes. Folia Cryptog. Estonica 52: 109-127. doi:10.12697/fce.2015.52.14.

741 Walser, J.-C. 2004. Molecular evidence for limited dispersal of vegetative propagules in

742 the epiphytic lichen Lobaria pulmonaria. Am. J. Bot. 91: 1273-1276.

743 doi:10.3732/ajb.91.8.1273.

744 Weih, M., Karacic, A., Munkert, H., Verwijst, T., and Diekmann, M. 2003. Influence of

745 young poplar stands on floristic diversity in agricultural landscapes (Sweden). Basic

$746 \quad$ Appl. Ecol. 4: 149-156. doi:10.1078/1439-1791-00157.

747 Will-Wolf, S., Esseen, P.A., and Neitlich, P. 2002. Monitoring biodiversity and ecosystem

748 function: forests. In Monitoring with Lichens - Monitoring Lichens, vol. 7. Edited by 
749 P.L. Nimis,, C. Scheidegger and P.A. Wolseley. Kluwer Academic Publishers, Dordrecht,

750 The Netherlands. pp. 203-222. doi:10.1007/978-94-010-0423-7_14.

751 Wirth, V. 2010. Ökologische Zeigerwerte von Flechten - erweiterte und aktualisierte

752 Fassung. Herzogia 23: 229-248. doi:10.13158/heia.23.2.2010.229. 
753 Table 1. Main characteristics of the study plots in midterm hybrid aspen plantations.

\begin{tabular}{|c|c|c|c|c|}
\hline Characteristic & Abbr. & Mean \pm SE & Min & Max \\
\hline \multicolumn{5}{|l|}{ Tree-layer and environmental variables } \\
\hline Tree height (m) & $\mathrm{H}$ & $18.9 \pm 0.8$ & 11.3 & 22.2 \\
\hline Tree diameter at breast height $(\mathrm{cm})$ & $\mathrm{DBH}$ & $14.9 \pm 0.7$ & 7.9 & 18.4 \\
\hline Density of trees (trees $\mathrm{ha}^{-1}$ ) & Den_T & $940 \pm 51.5$ & 600.0 & 1300.0 \\
\hline Basal area of trees $\left(\mathrm{m}^{2} \mathrm{ha}^{-1}\right)$ & $\mathrm{BA}$ & $18.2 \pm 2.0$ & 5.8 & 33.4 \\
\hline Soil $\mathrm{pH}_{\mathrm{KCl}}$ & $\mathrm{S} \_\mathrm{pH}$ & $5.4 \pm 0.2$ & 4.1 & 6.8 \\
\hline Soil P (mg kg $\left.{ }^{-1}\right)$ & $\mathrm{S} \_\mathrm{P}$ & $101.2 \pm 13.0$ & 36.0 & 203.0 \\
\hline Soil K (mg kg $\left.{ }^{-1}\right)$ & S_K & $110.5 \pm 14.2$ & 44.0 & 211.0 \\
\hline Soil organic C (\%) & S_C & $1.2 \pm 0.2$ & 0.5 & 2.7 \\
\hline Soil N (\%) & S_N & $0.1 \pm 0.007$ & 0.1 & 0.2 \\
\hline Canopy openness (\%) & Can_O & $16.1 \pm 1.7$ & 8.4 & 28.2 \\
\hline Transmitted total radiation (mol m-2 d-1) & Tr_TR & $6.2 \pm 0.7$ & 3.3 & 10.8 \\
\hline \multicolumn{5}{|l|}{ Landscape-scale variables } \\
\hline $\begin{array}{l}\text { Distance from continuous forest, growing } \\
\text { since 1935-1939 (m) }\end{array}$ & Dis_O & $314.3 \pm 45.0$ & 70.0 & 670.0 \\
\hline Distance from forest in $2015(\mathrm{~m})$ & Dis_C & $211 \pm 46.1$ & 35.0 & 670.0 \\
\hline $\begin{array}{l}\text { Forest area in the radius of } 500 \mathrm{~m} \text { around } \\
\text { the study plot in } 1930 \mathrm{~s} \text { (ha) }\end{array}$ & For_O & $8.3 \pm 2.8$ & 0.1 & 0.25 \\
\hline $\begin{array}{l}\text { Forest area in the radius of } 500 \mathrm{~m} \text { around } \\
\text { the study plot in } 2000 \text { (ha) }\end{array}$ & For_C & $35.3 \pm 7.04$ & 36.5 & 78 \\
\hline
\end{tabular}


755 Table 2. List of recorded lichen species, their frequency (percentage of occurrences) and substrate in the study plots ( $\mathrm{n}=15$ ) of midterm

756 hybrid aspen plantations, frequency class in Estonia, functional groups, type of reproductive diaspores, and ecological indicator values.

\begin{tabular}{|c|c|c|c|c|c|c|c|c|c|c|c|c|}
\hline & $\begin{array}{l}\text { Species } \\
\text { abbreviation }\end{array}$ & Frequency & & Frequency & Functional & I Reproductive & & & & & $\begin{array}{l}\text { cal } \\
\text { ralu }\end{array}$ & des $^{e}$ \\
\hline Species & (on Fig. 5) & $(\%)$ & Substrate $^{a}$ & $a \quad \mathrm{cl}^{b}$ & groups $^{c}$ & diaspores $^{d}$ & $\mathrm{~L}$ & $\mathrm{~T}$ & & $\mathrm{~F}$ & $\mathrm{R}$ & $\mathrm{N}$ \\
\hline Arthonia mediella Nyl. & Arth.med & 13 & $\mathrm{P}$ & st fq & sex cru & ap & & & & & & \\
\hline Arthonia patellulata Nyl. & Arth.pat & 67 & $\mathrm{P}$ & st $r$ & sex cru & ap & & & & & & \\
\hline Athallia cerinella (Nyl.) Arup et al. & Calo.cla & 53 & $\mathrm{P}$ & $\mathrm{r}$ & sex cru & ap & 7 & 6 & & 3 & 7 & \\
\hline $\begin{array}{l}\text { Athallia pyracea (Ach.) Arup et al. } \\
\text { Caloplaca cerina (Ehrh. ex Hedw.) Th. }\end{array}$ & Calo.pyr & 100 & $\mathrm{P}, \mathrm{S}$ & $\mathrm{fq}$ & sex cru & ap & 7 & $x$ & & 3 & 7 & 5 \\
\hline Fr. & Calo.cna & 100 & $\mathrm{P}$ & fqq & sex cru & ap & 7 & $\mathrm{x}$ & & 5 & 7 & 5 \\
\hline $\begin{array}{l}\text { Candelariella lutella (Vain.) Räsänen } \\
\text { Diplotomma pharcidium (Ach.) M. }\end{array}$ & Cand.lut & 87 & $\mathrm{~B}, \mathrm{P}$ & st fq & sex cru & ap & & & & & & \\
\hline Choisy & Dipl.pha & 7 & $\mathrm{P}$ & st $r$ & sex cru & ap & & & & & & \\
\hline $\begin{array}{l}\text { Evernia prunastri (L.) Ach. } \\
\text { Gyalolechia flavorubescens (Huds.) }\end{array}$ & Ever.pru & 47 & $\mathrm{P}$ & fqq & veg fru & sor & 7 & 5 & & 4 & 3 & 4 \\
\hline Søchting et al. & Calo.fla & 87 & $\mathrm{P}$ & fqq & sex cru & ap & & & & & & \\
\hline Hypogymnia physodes (L.) Nyl. & Hypo.phy & 47 & $\mathrm{P}$ & fqq & veg fol & sor & 7 & $\mathrm{x}$ & & 3 & 3 & \\
\hline Hypogymnia tubulosa (Schaer.) Hav. & Hypo.tub & 7 & $\mathrm{P}$ & fqq & veg fol & sor & 7 & 5 & & 3 & 5 & 4 \\
\hline $\begin{array}{l}\text { Lecania cyrtella (Ach.) Th. Fr. } \\
\text { Lecania naegelii (Hepp) Diederich \& }\end{array}$ & L.ia.cyr & 93 & $\mathrm{P}$ & $\mathrm{fq}$ & sex cru & ap & 7 & 5 & & 3 & 7 & 6 \\
\hline Van den Boom & L.ia.nae & 100 & $\mathrm{P}$ & $\mathrm{fq}$ & sex cru & ap & 6 & 5 & & 3 & 7 & 7 \\
\hline Lecanora argentata (Ach.) Malme & Leca.arg & 40 & $\mathrm{~B}, \mathrm{P}$ & fqq & sex cru & ap & 5 & 5 & & 4 & 5 & 3 \\
\hline Lecanora carpinea (L.) Vain. & Lec.car & 73 & $\mathrm{~B}, \mathrm{P}$ & fqq & sex cru & ap & 6 & 5 & & 3 & 5 & 4 \\
\hline Lecanora chlarotera Nyl. & Leca.chl & 100 & $\mathrm{P}$ & fqq & sex cru & ap & 6 & 5 & & 3 & 6 & 5 \\
\hline Lecanora leptyrodes (Nyl.) Degel. & Leca.lep & 80 & $\mathrm{P}, \mathrm{S}$ & fqq & sex cru & ap & & & & & & \\
\hline Lecanora populicola (DC.) Duby & Leca.pop & 67 & $\mathrm{P}$ & $\mathrm{fq}$ & sex cru & ap & & & & & & \\
\hline Lecanora pulicaris (Pers.) Ach. & Leca.pul & 7 & $P$ & fqq & sex cru & ap & 7 & 4 & & 3 & 3 & 4 \\
\hline
\end{tabular}




\begin{tabular}{|c|c|c|c|c|c|c|c|c|c|c|}
\hline Lecanora sambuci (Pers.) Nyl. & Leca.sam & 87 & $\mathrm{P}$ & st fq & sex cru & ap & 7 & 6 & 3 & 7 \\
\hline Lecanora symmicta (Ach.) Ach. & Leca.sym & 87 & $\mathrm{~B}, \mathrm{P}$ & fqq & sex cru & ap & 7 & 4 & 5 & 5 \\
\hline Lecidella elaeochroma (Ach.) M. Choisy & Leci.ela & 67 & $\mathrm{P}$ & fqq & sex cru & ap & 6 & 5 & 3 & 6 \\
\hline Lecidella euphorea (Flörke) Hertel & Leci.eup & 87 & $\mathrm{P}$ & fqq & sex cru & ap & & & & \\
\hline Leptorhaphis tremulae Körb. & & 7 & $\mathrm{P}$ & $\mathrm{r}$ & sex cru & per & & & & \\
\hline $\begin{array}{l}\text { Melanelixia subaurifera (Nyl.) O. Blanco } \\
\text { et al. }\end{array}$ & Mela.sub & 60 & $\mathrm{P}$ & fqq & veg fol & sor & 6 & 5 & 5 & 6 \\
\hline $\begin{array}{l}\text { Melanohalea olivacea (L.) O. Blanco et } \\
\text { al. } \\
\text { Mycomicrothelia wallrothii (Hepp) D. }\end{array}$ & Mela.oli & 40 & $\mathrm{~B}, \mathrm{P}$ & fqq & sex fol & ap & & & & \\
\hline Hawksw. & Myco.wal & 13 & $\mathrm{P}$ & st fq & sex cru & per & & & & \\
\hline Parmelia sulcata Taylor & Parm.sul & 67 & $\mathrm{P}$ & fqq & veg fol & sor & 7 & $\mathrm{x}$ & 3 & 5 \\
\hline Peltigera rufescens (Weiss) Humb. & & 7 & G & fqq & sex fol & ap & 8 & $\mathrm{x}$ & 3 & 8 \\
\hline $\begin{array}{l}\text { Phaeophyscia ciliata (Hoffm.) Moberg } \\
\text { Phaeophyscia orbicularis (Neck.) }\end{array}$ & Phae.cil & 87 & $\mathrm{P}$ & $\mathrm{fq}$ & sex fol & ap & & & & \\
\hline Moberg & Phae.orb & 7 & $P$ & fqq & veg fol & sor & 7 & $\mathrm{x}$ & $\mathrm{x}$ & 7 \\
\hline Physcia adscendens (Fr.) H. Olivier & Phys.ads & 93 & $\mathrm{P}$ & fqq & veg fol & sor & 7 & $\mathrm{x}$ & 3 & 7 \\
\hline Physcia aipolia (Ehrh. ex Humb.) Fürnr. & Phys.aip & 7 & $\mathrm{P}$ & fqq & sex fol & ap & 7 & $\mathrm{x}$ & 3 & 7 \\
\hline Physcia stellaris (L.) Nyl. & Phys.ste & 93 & $\mathrm{P}$ & fqq & sex fol & ap & 7 & 4 & 3 & 6 \\
\hline Physcia tenella (Scop.) DC. & Phys.ten & 87 & $\mathrm{P}$ & fqq & veg fol & sor & 7 & $\mathrm{x}$ & 3 & 6 \\
\hline Physconia distorta (With.) J.R. Laundon & Phys.dis & 47 & $\mathrm{P}$ & fqq & sex fol & ap & 7 & 5 & 5 & 7 \\
\hline Ramalina farinacea (L.) Ach. & Ram.far. & 80 & $\mathrm{~B}, \mathrm{P}$ & fqq & veg fru & sor & 6 & 5 & 4 & 5 \\
\hline Rinodina exigua Gray & Rino.exi & 27 & $\mathrm{~B}, \mathrm{P}$ & $\mathrm{fq}$ & sex cru & ap & 7 & 5 & 3 & 7 \\
\hline $\begin{array}{l}\text { Rinodina pyrina (Ach.) Arnold } \\
\text { Scoliciosporum chlorococcum (Stenh.) }\end{array}$ & Rino.pyr & 60 & $\mathrm{P}$ & $\mathrm{fq}$ & sex cru & ap & 7 & 4 & 5 & 7 \\
\hline $\begin{array}{l}\text { Vězda } \\
\text { Scoliciosporum sarothamni (Vain.) }\end{array}$ & Scol. chl & 7 & B & $\mathrm{fq}$ & sex cru & ap & 6 & 5 & 3 & 3 \\
\hline $\begin{array}{l}\text { Vězda } \\
\text { Tuckermannopsis chlorophylla (Willd.) }\end{array}$ & Scol.sar & 47 & $\mathrm{~B}, \mathrm{P}$ & st fq & veg cru & sor & & & & \\
\hline Hale & Tuck.chl & 7 & $\mathrm{P}$ & fqq & veg fru & sor & 6 & 4 & 6 & 3 \\
\hline
\end{tabular}




\begin{tabular}{|c|c|c|c|c|c|c|c|c|c|c|}
\hline $\begin{array}{l}\text { Xanthoria parietina (L.) Th. Fr. } \\
\text { Xanthoria polycarpa (Hoffm.) Th. Fr. ex }\end{array}$ & Xant.par & 100 & $\mathrm{P}$ & fqq & sex fol & ap & 7 & $\mathrm{x}$ & 3 & 7 \\
\hline Rieber & Xant.pol & 73 & $B, P$ & fqq & sex fol & ap & 7 & $\mathrm{x}$ & 3 & 7 \\
\hline
\end{tabular}

${ }^{a} \mathrm{~B}-$ Betula spp., G - ground, P - P. tremula $\times$ P. tremuloides, $\mathrm{S}-$ Salix spp.

bfqq - very frequent, 51 or more localities; fq - frequent, 21-50 localities; st fq - rather frequent, 11-20 localities; st $r$ - rather rare, 6-10 localities; $r$ - rare, 3-5 localities (according to Randlane et al. 1999)

${ }^{c}$ sex cru - sexually reproducing crustose species, sex fol - sexually reproducing foliose species, veg cru - vegetatively reproducing crustose species, veg fol - vegetatively reproducing foliose species, veg fru - vegetatively reproducing fruticose species (traits based on Smith et al. 2009)

$d_{\text {ap }}$ - species with apothecia, per - species with perithecia, sor - species dispersing with soredia ${ }^{e} \mathrm{~L}$ - light value (5 - sites in half-shade, 6 - intermediate value between 5 and 7, 7 - sites in half-light, 8 - sites in light), Ttemperature value $(3$ - cool areas, 4 - intermediate value between 3 and 5, 5 - moderately cool to moderately warm areas, 6 mostly mild areas), F - moisture value (3 - dry habitats tolerated but often also in moist habitats, 4 - also in dry habitats but only at high air moisture, 5 - dry habitats usually avoided, precipitation mainly over $700 \mathrm{~mm} / \mathrm{yr}, 6$ - precipitation usually over 800 $\mathrm{mm} / \mathrm{yr}$ ), $\mathrm{R}$ - reaction (acidity) value (3 - rather acid, $\mathrm{pH} 4.1-4.8 ; 5$ - moderate acid, pH 4.5-5.6; 6 - weakly acid, $\mathrm{pH}$ 5.3-6.1; 7 subneutral, pH 5.7-6.5; 8 - neutral, pH 6.6-7.5), $\mathrm{N}$ - eutrophication value (3-4 - weak/rather weak eutrophication, 5-6 moderate/clear eutrophication, 7 - rather strong eutropication, 8 - strong eutrophication, 9 - very strong eutrophication) according to Wirth (2010); $\mathrm{x}$ - the value is determined as 'of broad amplitude' by Wirth (2010). 
758 Table 3. List of recorded bryophyte species, their frequency (percentage of occurrences) and substrate in the study plots ( $\mathrm{n}=15$ ) of

759 midterm hybrid aspen plantations, frequency class in Estonia, life strategy categories, and ecological indicator values.

\begin{tabular}{|c|c|c|c|c|c|c|c|c|c|}
\hline \multirow[b]{2}{*}{ Species } & \multirow{2}{*}{$\begin{array}{l}\text { Species } \\
\text { abbreviation } \\
\text { (on Fig. 6) }\end{array}$} & \multirow{2}{*}{$\begin{array}{c}\text { Frequency } \\
(\%)\end{array}$} & \multirow{2}{*}{ Substrate ${ }^{a}$} & \multirow{2}{*}{$\begin{array}{l}\text { Frequency } \\
\mathrm{cl}^{b} \\
\end{array}$} & \multirow{2}{*}{$\begin{array}{r}\text { Life strategy } \\
\text { categories }^{c}\end{array}$} & \multicolumn{4}{|c|}{$\begin{array}{c}\text { Ecological } \\
\text { indicator values } \\
\end{array}$} \\
\hline & & & & & & $\mathrm{L}$ & $\mathrm{T}$ & $\mathrm{F}$ & $\mathrm{R}$ \\
\hline Amblystegium serpens (Hedw.) Schimp. & Ambl.ser & 100 & $G, P, W$ & $\mathrm{fq}$ & $\mathrm{p}$ & 5 & & 4 & 6 \\
\hline $\begin{array}{l}\text { Atrichum undulatum (Hedw.) P. Beauv. } \\
\text { Brachytheciastrum velutinum (Hedw.) Ignatov \& }\end{array}$ & Atri.und & 33 & G & $\mathrm{fq}$ & s & 6 & & 6 & 4 \\
\hline Huttunen & Brac.vel & 13 & G & $\mathrm{fq}$ & $\mathrm{p}$ & 5 & 3 & 4 & 6 \\
\hline Brachythecium erythrorrhizon Schimp. & Brac.ery & 13 & G & $\mathrm{fq}$ & $\mathrm{p}$ & 8 & 1 & 7 & 6 \\
\hline Brachythecium mildeanum (Schimp.) Schimp. & Brac.mil & 7 & G & $\mathrm{fq}$ & $\mathrm{p}$ & 8 & 4 & 7 & 6 \\
\hline Brachythecium rivulare Schimp. & Brac.riv & 33 & G & $\mathrm{fq}$ & $\mathrm{pc}$ & & 3 & 7 & 5 \\
\hline Brachythecium rutabulum (Hedw.) Schimp. & Brac.rut & 100 & $\mathrm{G}, \mathrm{P}$ & $\mathrm{fq}$ & $\mathrm{cp}$ & 5 & & 4 & \\
\hline Brachythecium salebrosum (Hoffm. ex F. Weber \& D. & & & & & & & & & \\
\hline Mohr) Schimp. & Brac.sal & 93 & $\mathrm{G}, \mathrm{P}, \mathrm{W}$ & $\mathrm{fq}$ & $\mathrm{cp}$ & 6 & 4 & 4 & 5 \\
\hline Calliergonella cuspidata (Hedw.) Loeske & Call.cus & 40 & G, P & $\mathrm{fq}$ & $\mathrm{pc}$ & 8 & 3 & 7 & 7 \\
\hline Campylidium sommerfeltii (Myrin) Ochyra & Camp.som & 47 & $\mathrm{G}, \mathrm{P}$ & $\mathrm{fq}$ & $\mathrm{p}$ & 3 & 1 & 6 & 4 \\
\hline Chiloscyphus pallescens (Ehrh. ex Hoffm.) Dumort. & Chil.pal & 7 & G & $\mathrm{fq}$ & pc & 5 & 3 & 8 & 7 \\
\hline Chiloscyphus polyanthos (L.) Corda & Chil.pol & 13 & $\mathrm{G}$ & fq & pc & & 4 & 9 & 2 \\
\hline Cirriphyllum piliferum (Hedw.) Grout & Cirr.pil & 60 & $\mathrm{G}, \mathrm{P}$ & $\mathrm{fq}$ & $\mathrm{pc}$ & 7 & 3 & 5 & 6 \\
\hline Eurhynchiastrum pulchellum (Hedw.) Ignatov \& & & & & & & & & & \\
\hline Huttunen & Eurh.pul & 7 & G & $\mathrm{fq}$ & ps & 6 & 4 & 4 & 6 \\
\hline Eurhynchium angustirete (Broth.) T.J. Kop. & Eurh.ang & 27 & $\mathrm{G}, \mathrm{P}$ & $\mathrm{fq}$ & $\mathrm{p}$ & 5 & 4 & 4 & 7 \\
\hline Hygroamblystegium varium (Hedw.) Mönk. & Hygr.var & 7 & $\mathrm{G}$ & $\mathrm{fq}$ & $\mathrm{p}$ & 5 & 5 & 5 & 6 \\
\hline Hylocomium splendens (Hedw.) Schimp. & Hylo.spl & 13 & G & $\mathrm{fq}$ & pc & 6 & 3 & 4 & 5 \\
\hline Hypnum cupressiforme Hedw. & Hypn.cup & 13 & $\mathrm{G}, \mathrm{W}$ & $\mathrm{fq}$ & ps & 5 & & 4 & 4 \\
\hline Kindbergia praelonga (Hedw.) Ochyra & Kind.pra & 33 & $G, P$ & $\mathrm{fq}$ & $\mathrm{p}$ & 6 & 4 & 6 & 5 \\
\hline Leptobryum pyriforme (Hedw.) Wilson & Lept.pyr & 7 & $\mathrm{G}$ & $\mathrm{fq}$ & $\mathrm{f}$ & & & 6 & 7 \\
\hline
\end{tabular}


Leskea polycarpa Hedw.

Lophocolea heterophylla (Schrad.) Dumort Orthotrichum speciosum Nees

Oxyrrhynchium hians (Hedw.) Loeske

Pellia sp.

Plagiomnium affine (Blandow ex Funck) T.J. Kop.

Plagiomnium cuspidatum (Hedw.) T.J. Kop.

Plagiomnium medium (Bruch \& Schimp.) T.J. Kop.

Plagiomnium undulatum (Hedw.) T.J. Kop.

Pleurozium schreberi (Willd. ex Brid.) Mitt.

Pohlia sp.

Pylaisia polyantha (Hedw.) Schimp.

Rhizomnium punctatum (Hedw.) T.J. Kop.

Rhytidiadelphus squarrosus (Hedw.) Warnst.

Rhytidiadelphus triquetrus (Hedw.) Warnst.

Sanionia uncinata (Hedw.) Loeske

Sciuro-hypnum curtum (Lindb.) Ignatov

Sciuro-hypnum reflexum (Starke) Ignatov \& Huttunen

Tortula truncata (Hedw.) Mitt.

\begin{tabular}{lrccccccc} 
Lesk.pol & 7 & $\mathrm{P}$ & $\mathrm{p}$ & $\mathrm{p}$ & 7 & 5 & 4 & 7 \\
Loph.het & 47 & $\mathrm{G}, \mathrm{P}$ & $\mathrm{fq}$ & $\mathrm{cp}$ & 4 & 3 & 4 & 3 \\
Orth.spe & 47 & $\mathrm{P}$ & $\mathrm{fq}$ & $\mathrm{s}$ & 7 & 2 & 5 & 5 \\
Oxyr.hia & 100 & $\mathrm{G}, \mathrm{P}, \mathrm{W}, \mathrm{S}$ & $\mathrm{fq}$ & $\mathrm{cp}$ & 7 & 4 & 5 & 7 \\
Pell.sp & 7 & $\mathrm{G}$ & & & & & & \\
Plag.aff & 33 & $\mathrm{G}$ & $\mathrm{fq}$ & $\mathrm{pc}$ & 5 & 4 & 5 & 5 \\
Plag.cus & 87 & $\mathrm{G}, \mathrm{P}, \mathrm{W}$ & $\mathrm{fq}$ & $\mathrm{pc}$ & 4 & 3 & 5 & 7 \\
Plag.med & 7 & $\mathrm{G}$ & $\mathrm{p}$ & $\mathrm{pc}$ & 5 & 1 & 7 & 5 \\
Plag.und & 7 & $\mathrm{G}$ & $\mathrm{fq}$ & $\mathrm{pc}$ & 4 & 3 & 6 & 6 \\
Pleu.sch & 20 & $\mathrm{G}$ & $\mathrm{fq}$ & $\mathrm{pc}$ & 6 & 3 & 4 & 2 \\
Pohl.sp & 13 & $\mathrm{G}$ & & & & & & \\
Pyla.pol & 73 & $\mathrm{P}$ & $\mathrm{fq}$ & $\mathrm{ps}$ & 8 & 3 & 5 & 7 \\
Rhiz.pun & 7 & $\mathrm{G}$ & $\mathrm{fq}$ & $\mathrm{l}$ & 3 & 3 & 6 & 4 \\
Rhyt.squ & 13 & $\mathrm{G}$ & $\mathrm{fq}$ & $\mathrm{pc}$ & 7 & 3 & 6 & 5 \\
Rhyt.tri & 13 & $\mathrm{G}$ & $\mathrm{fq}$ & $\mathrm{pc}$ & 7 & 3 & 4 & 5 \\
Sani.unc & 13 & $\mathrm{G}, \mathrm{P}$ & $\mathrm{fq}$ & $\mathrm{ps}$ & & & 7 & 3 \\
Schy.cur & 87 & $\mathrm{G}, \mathrm{P}, \mathrm{W}$ & $\mathrm{fq}$ & $\mathrm{pc}$ & 3 & 4 & 6 & 3 \\
& & & & & & & & \\
Schy.ref & 13 & $\mathrm{G}, \mathrm{W}$ & $\mathrm{fq}$ & $\mathrm{ps}$ & 4 & 2 & 5 & 4 \\
Tort.tru & 7 & $\mathrm{G}$ & $\mathrm{p}$ & $\mathrm{a}$ & 7 & 4 & 7 & 5 \\
\hline
\end{tabular}

${ }^{a} \mathrm{G}$ - ground, $\mathrm{P}-$ P. tremula $\times$ P. tremuloides, $\mathrm{S}-$ Salix spp., $\mathrm{W}$ - deadwood

$b \mathrm{fq}$ - frequent, 31 or more localities; $\mathrm{p}$ - sporadically, 8-30 localities (according to Vellak et al. 2015)

${ }^{c_{S}}$ - short-lived shuttle, a - annual shuttle, cp - pioneer colonists, $\mathrm{f}$ - fugitives, $\mathrm{l}$ - long-lived shuttle, $\mathrm{p}$ - perennials, $\mathrm{pc}$ - competitive perennials, ps - stress tolerant perennials (according to Dierssen 2001)

${ }^{d} \mathrm{~L}$ - light value ( 3 - shade species, 4 intermediate value between 3 and 5, 5 - half-shade species, 6 - intermediate value between 5 and 7, 7 - half-light species, 8 - light species), T - temperature value (1 - cold areas, 2 - intermediate value between 1 and 3,3 cool areas, 4 - intermediate value between 3 and 5, 5 - moderately warm areas), F - moisture value ( 4 - intermediate value between 3 (dry habitats) and 5, 5 - moderately moist habitats, 6 - intermediate value between 5 and 7, 7 - moist habitats, 8 intermediate value between 7 and 9, 9 - temporarily water-logged habitats) and R - reaction (acidity) value (2 - intermediate value 
between 1 (strongly acid) and 3; 3 - acid, $\mathrm{pH}<5 ; 4$ - intermediate value between 3 and $5 ; 5$ - moderately acid, pH 5.0-6.0; 6intermediate value between 5 and 7; 7 - weakly acid to weakly neutral, pH 6.0-6.9); - species with broad amplitude (according to Düll 1991) 
761 Table 4. Best models (with delta AICc < 2) describing lichen and bryophyte species

762 richness in hybrid aspen plantations.

\begin{tabular}{|c|c|c|c|c|c|c|c|}
\hline Dependent & $\begin{array}{l}\text { Delta } \\
\text { AICc }\end{array}$ & $\mathrm{R}^{2}$ adj & $\begin{array}{c}\text { Independent } \\
\text { variable }\end{array}$ & Estimate & SE & $\mathrm{t}$ & $P$ \\
\hline \multirow[t]{3}{*}{$\begin{array}{l}\text { Lichen species } \\
\text { richness }\end{array}$} & 0 & 0.36 & $\begin{array}{c}\text { Forest area in } \\
1930 \mathrm{~s}\end{array}$ & 0.07 & 0.02 & 3.0 & 0.011 \\
\hline & \multirow[t]{2}{*}{1.05} & \multirow[t]{2}{*}{0.42} & Soil K & 0.14 & 0.09 & 1.6 & 0.145 \\
\hline & & & $\begin{array}{c}\text { Forest area in } \\
1930 \mathrm{~s}\end{array}$ & 0.07 & 0.02 & 2.9 & 0.014 \\
\hline \multirow[t]{2}{*}{$\begin{array}{l}\text { Bryophyte species } \\
\text { richness }\end{array}$} & \multirow[t]{2}{*}{0} & \multirow[t]{2}{*}{0.58} & $\begin{array}{c}\text { Forest area in } \\
1930 \mathrm{~s}\end{array}$ & 0.09 & 0.02 & 3.9 & 0.002 \\
\hline & & & $\begin{array}{l}\text { Density of } \\
\text { trees }\end{array}$ & 0.59 & 0.20 & 3.0 & 0.012 \\
\hline
\end{tabular}

763 
764 Table 5. Relationships between lichen/bryophyte species compositions (NMDS

765 ordinations; Figures 5 and 6, accordingly) and environmental variables in midterm

766 hybrid aspen plantations.

\begin{tabular}{lllll}
\hline \multirow{2}{*}{ Environmental or landscape factor } & \multicolumn{2}{l}{ Lichens } & \multicolumn{2}{l}{ Bryophytes } \\
\cline { 2 - 6 } & $\mathrm{r}^{2}$ & $p$-value & $\mathrm{r}^{2}$ & $p$-value \\
\hline Tree height & 0.15 & 0.358 & 0.13 & 0.441 \\
Diameter at breast height & 0.17 & 0.291 & 0.24 & 0.198 \\
Tree density & 0.13 & 0.439 & 0.04 & 0.78 \\
Basal area & 0.03 & 0.844 & 0.08 & 0.612 \\
Soil pH & 0.15 & 0.373 & 0.02 & 0.899 \\
Soil P & 0.01 & 0.936 & 0.49 & $\mathbf{0 . 0 2 2}$ \\
Soil K & 0.19 & 0.268 & 0.03 & 0.84 \\
Soil organic C & 0.07 & 0.623 & 0.02 & 0.895 \\
Soil N & 0.2 & 0.228 & 0.24 & 0.19 \\
Canopy openness & 0.02 & 0.88 & 0.51 & $\mathbf{0 . 0 2 5}$ \\
Transmitted total radiation & 0.04 & 0.78 & 0.52 & $\mathbf{0 . 0 2 3}$ \\
Distance from continuous (since 1930s) & & & & \\
$\quad$ forest & 0.47 & $\mathbf{0 . 0 1 5}$ & 0.27 & 0.165 \\
Distance from forest in 2015 & 0.62 & $\mathbf{0 . 0 0 4}$ & 0.02 & 0.906 \\
Forest area in the vicinity in 1930s & 0.56 & $\mathbf{0 . 0 0 4}$ & 0.42 & $\mathbf{0 . 0 4 2}$ \\
Forest area in the vicinity in 2000 & 0.31 & 0.13 & 0.23 & 0.218 \\
\hline
\end{tabular}

767 Note: The $r^{2}$ values indicate the strength of correlation between respective environmental or 768 landscape-scale factor and the NMDS ordination axes scores. $P$-values are based on random 769 permutations of the data; significant $(p<0.05)$ relationships are indicated in bold.

770 
771 Table A1. Correlation matrix of studied environmental and landscape-scale variables, and species richnesses of bryophytes (Bry_R) and

772 lichens (Lic_R; for abbreviations of variables see Table 1) in midterm hybrid aspen plantations.

\begin{tabular}{|c|c|c|c|c|c|c|c|c|c|c|c|c|c|c|c|}
\hline & $\mathrm{H}$ & $\mathrm{DBH}$ & Den_T & BA & S_pH & S_P & S_K & S_C & S_N & Can_O & $\mathrm{Tr} \_\mathrm{TR}$ & Dis_O & Dis_C & Lic_R & Bry_R \\
\hline $\mathrm{H}$ & 1 & & & & & & & & & & & & & & \\
\hline $\mathrm{DBH}$ & 0,93 & 1 & & & & & & & & & & & & & \\
\hline Den_T & 0,31 & 0,15 & 1 & & & & & & & & & & & & \\
\hline BA & 0,89 & 0,86 & 0,62 & 1 & & & & & & & & & & & \\
\hline S_pH & $-0,14$ & $-0,21$ & 0,23 & $-0,08$ & 1 & & & & & & & & & & \\
\hline S_P & 0,28 & 0,41 & 0,01 & 0,34 & $-0,01$ & 1 & & & & & & & & & \\
\hline S_K & $-0,08$ & $-0,08$ & 0,09 & $-0,06$ & 0,61 & $-0,04$ & 1 & & & & & & & & \\
\hline S_C & 0,05 & 0,09 & 0,62 & 0,39 & 0,11 & $-0,05$ & 0,08 & 1 & & & & & & & \\
\hline S_N & $-0,24$ & $-0,32$ & 0,42 & $-0,03$ & 0,14 & $-0,47$ & 0,17 & 0,65 & 1 & & & & & & \\
\hline Can_O & $-0,27$ & $-0,44$ & $-0,24$ & $-0,43$ & $-0,18$ & $-0,49$ & $-0,18$ & $-0,21$ & 0,2 & 1 & & & & & \\
\hline Tr_TR & $-0,23$ & $-0,37$ & $-0,25$ & $-0,39$ & $-0,13$ & $-0,48$ & $-0,24$ & $-0,18$ & 0,18 & 0,98 & 1 & & & & \\
\hline Dis_O & $-0,37$ & $-0,5$ & $-0,09$ & $-0,42$ & 0,1 & $-0,2$ & 0,14 & $-0,22$ & 0,23 & 0,48 & 0,41 & 1 & & & \\
\hline Dis_C & $-0,11$ & $-0,24$ & $-0,02$ & $-0,18$ & 0,14 & $-0,35$ & $-0,32$ & 0,19 & 0,43 & 0,38 & 0,42 & 0,34 & 1 & & \\
\hline Lic_R & $-0,33$ & $-0,32$ & 0,11 & $-0,23$ & 0,05 & $-0,31$ & 0,4 & 0,1 & 0,28 & 0,18 & 0,08 & 0,64 & 0,02 & 1 & \\
\hline Bry_R & $-0,03$ & $-0,2$ & 0,45 & 0,06 & 0,08 & $-0,19$ & $-0,04$ & 0,08 & 0,18 & 0,17 & 0,12 & 0,62 & 0,37 & 0,56 & 1 \\
\hline
\end{tabular}




\section{Figure captions}

775 Figure 1. Location of the studied hybrid aspen plantations (indicated with grey circles)

776 in southern Estonia.

777

778 Figure 2. Distribution of recorded lichen and bryophyte species in groups according to 779 ecological indicator values of lichens (based on Wirth 2010) and bryophytes (based on 780 Düll 1991).

781

782

Figure 3. Correlation between total species richnesses of lichens and bryophytes in $10 \times$ $78310 \mathrm{~m}$ study plots (axes are in log-scale; type II regression line is used to depict the linear 784 relationship between significantly correlated variables).

785

786

787

788

Figure 4. Effect of environmental and landscape-scale parameters on species richness estimates for lichens and bryophytes within $10 \times 10 \mathrm{~m}$ study plots (axes are in log-scale). Only variables included to best models (Table 4) are shown.

789

790

Figure 5. NMDS ordination of study plots and lichen species (stress 0.12 ). The arrows

791 indicate the direction and strenth of correlation $\left(\mathrm{r}^{2}\right)$ for environmental vectors that

792 were significantly $(p<0.05)$ related to ordination (see also Table 5). Study plots are

793 indicated with grey circles. Forest abund. 1930s - forest area in the vicinity of study plot in 1930s, Distance 2015 - distance from study plot to natural forest in 2015, Distance 1930s - distance from study plot to continuous (since 1930s) forest. For abbreviations of species names see Table 2 .

797 
798 Figure 6. NMDS ordination of study plots and bryophyte species (stress 0.19). The 799 arrows indicate the direction and strength of correlation $\left(\mathrm{r}^{2}\right)$ for environmental vectors 800 that were significantly $(p<0.05)$ related to ordination (see also Table 5). Study plots are 801 indicated with grey circles. Forest abund. 1930s - forest area in the vicinity of study plot 802 in 1930s, Soil P - concentration of available P in soil A-horizon, Canopy open. - canopy 803 openness, Trans. total - transmitted total radiation. For abbreviations of species names see 804 Table 3. 


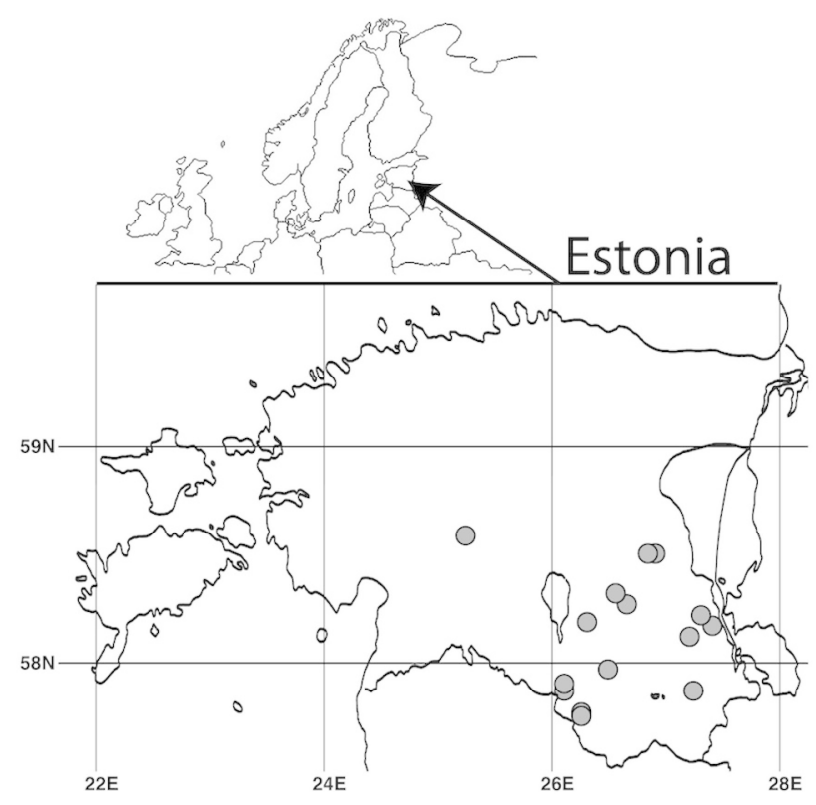

Figure 1. Location of the studied hybrid aspen plantations (indicated with grey circles) in southern Estonia. $203 \times 287 \mathrm{~mm}(300 \times 300 \mathrm{DPI})$ 
Page 47 of $50 \quad$ Canadian Journal of Forest 0 e.50
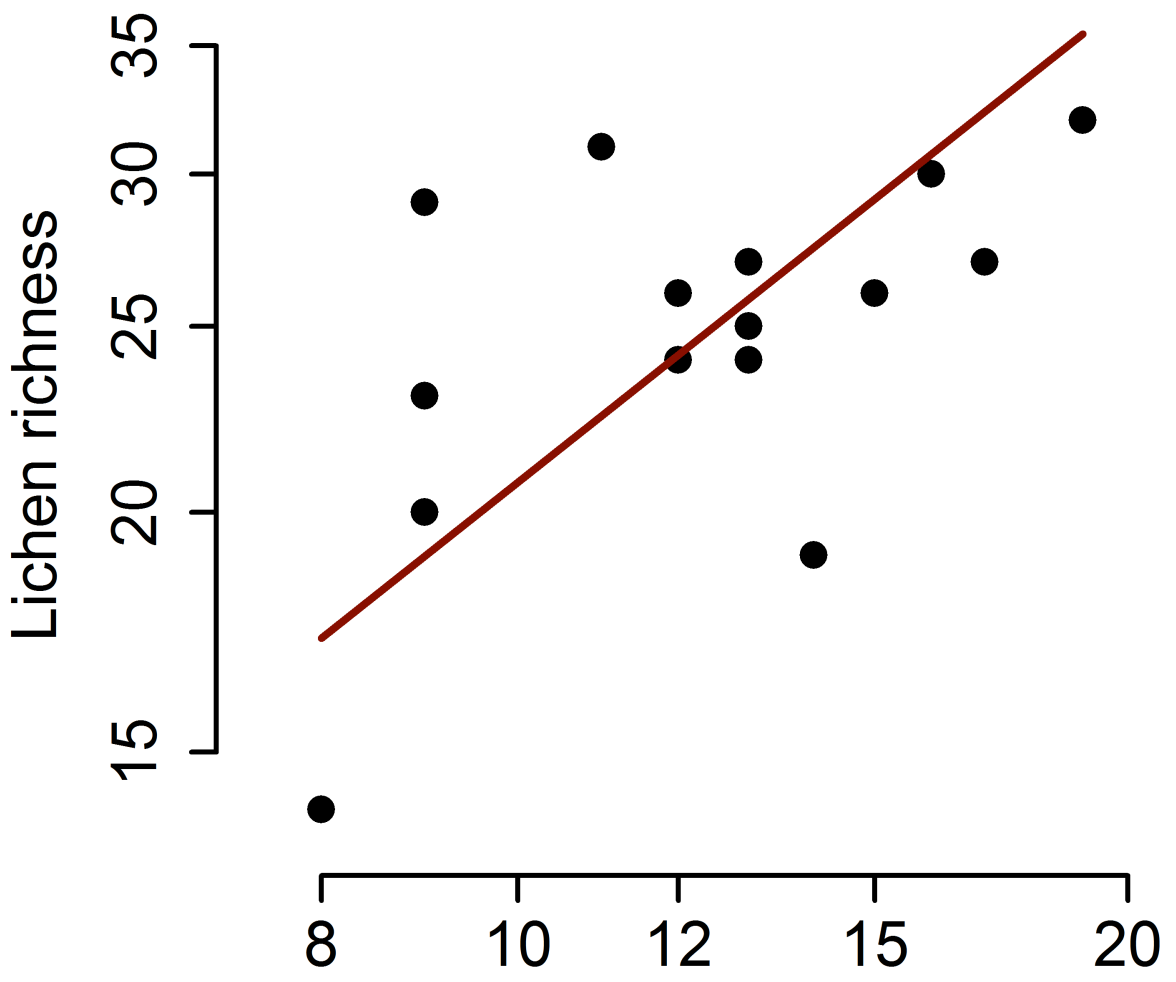

https://mc06.manuscriptcentral.com/cjfr-pubs Bryophyte richness 


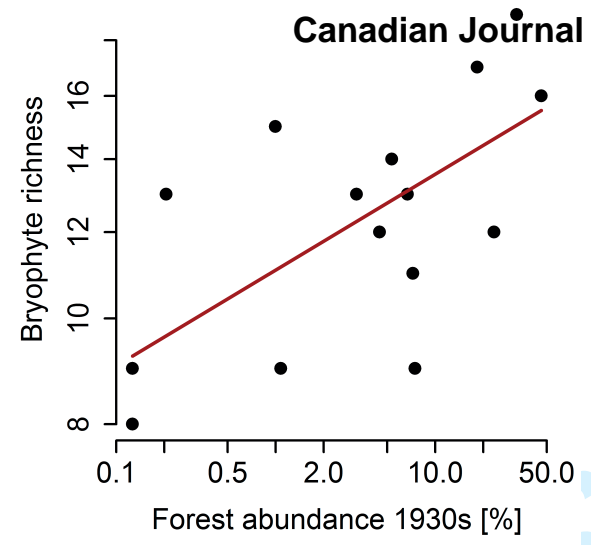

Page 48 of 50
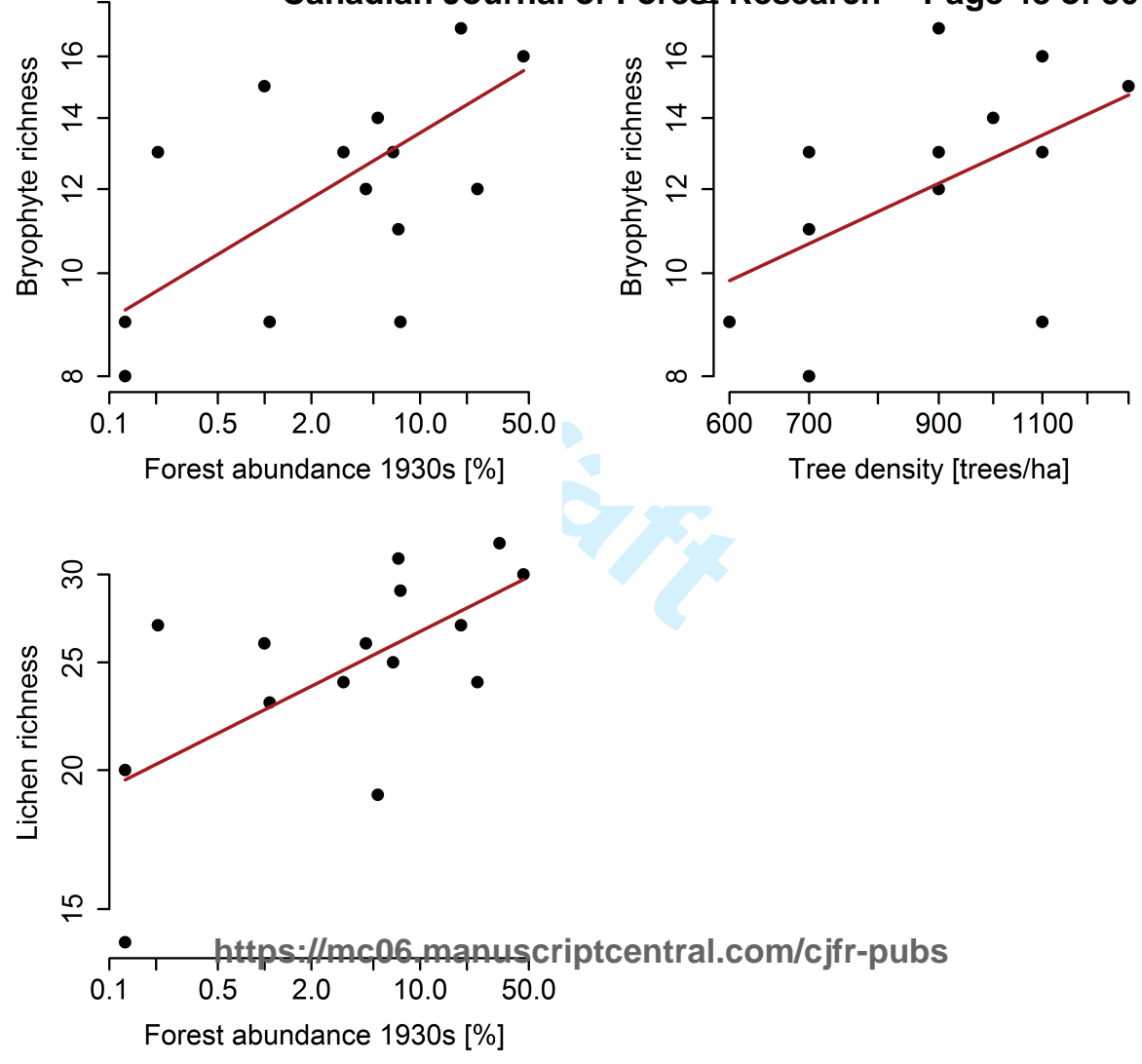


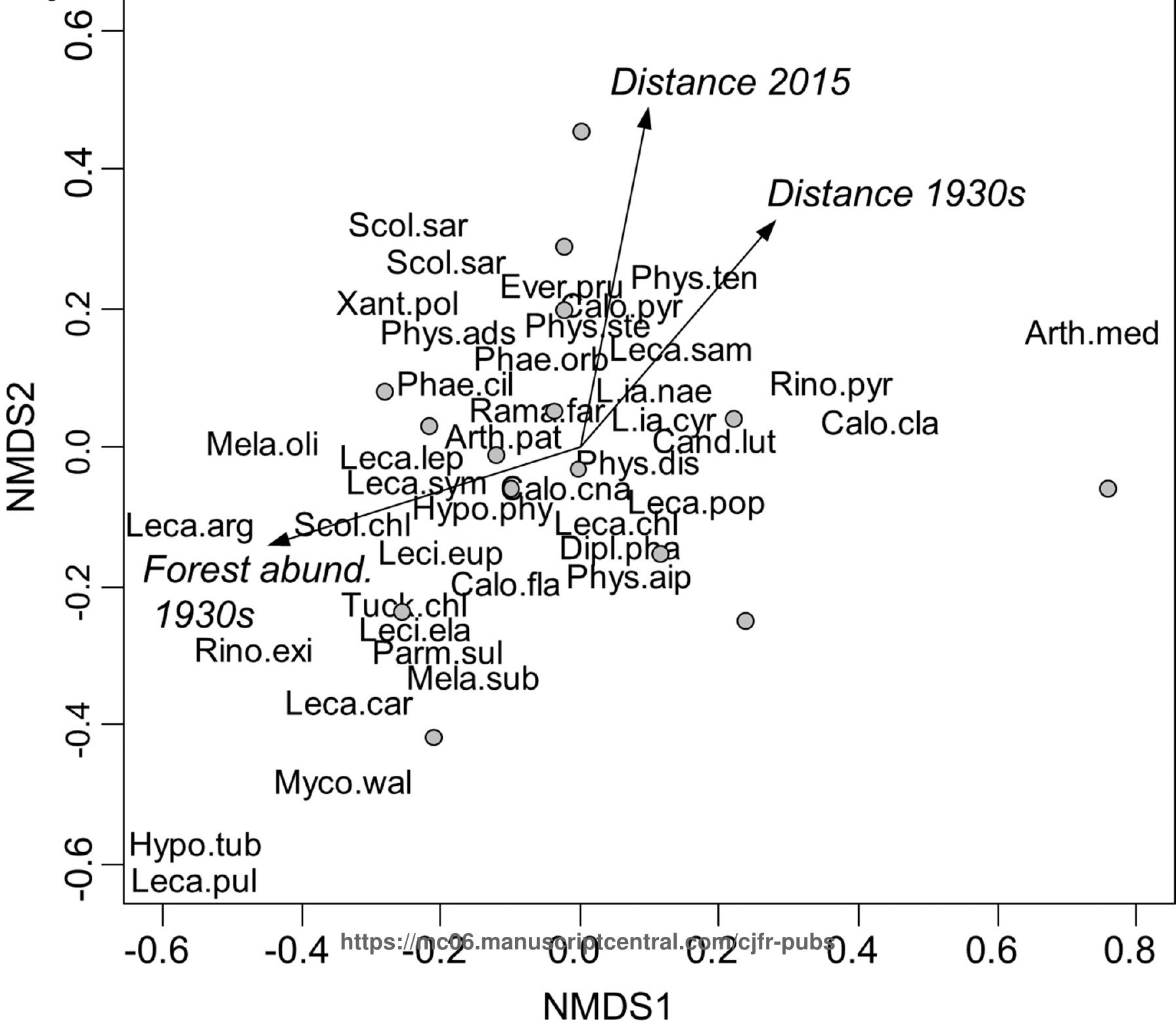




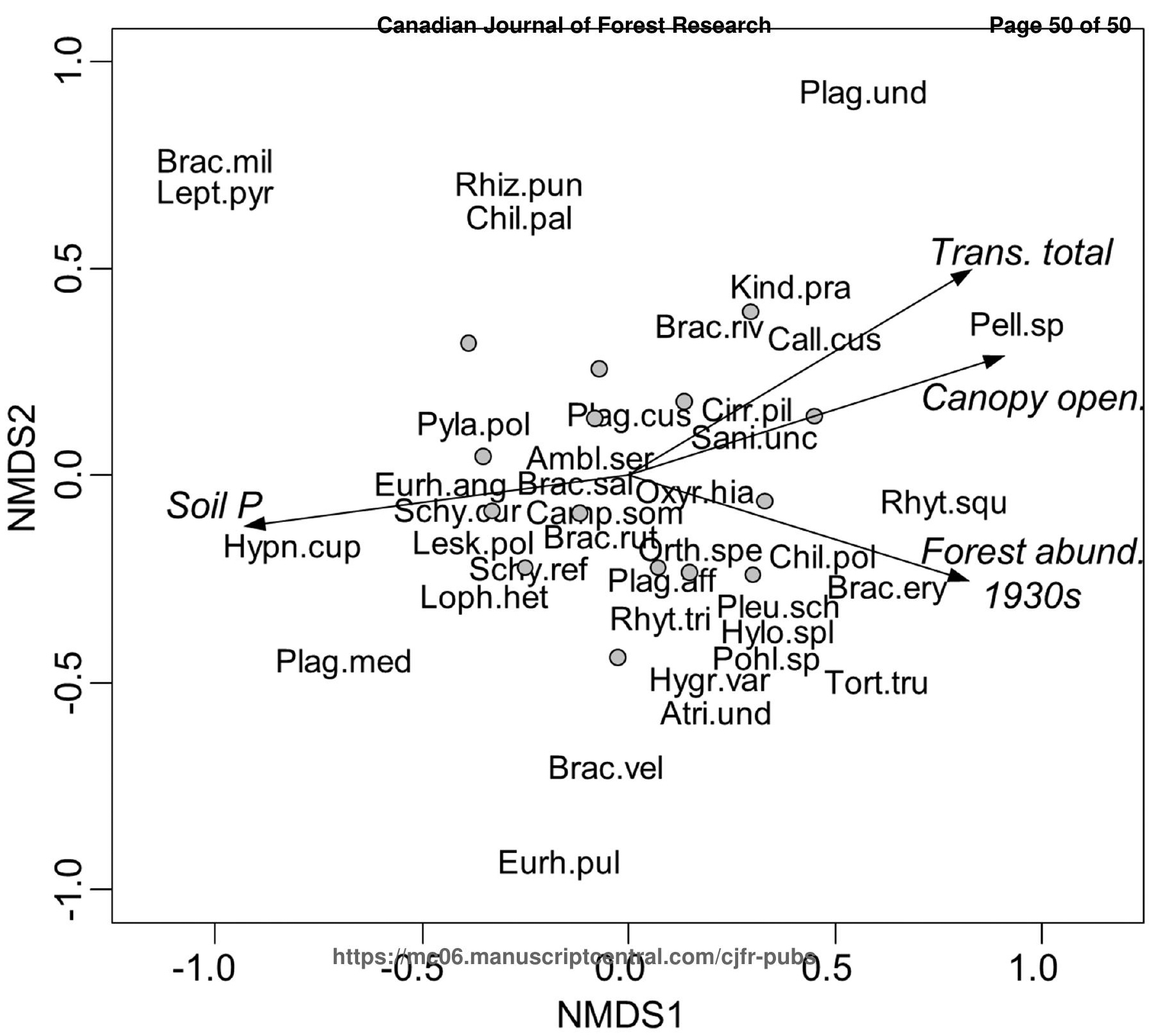

